\title{
الخطاب الفلسفي الأخلاقي بين الواقعية والرمزية:" مفكرو الغرب الإسلامي (أنموذجاً)
}

*** محمد علي الجندي

الملخص

تحدف هذه الدراسة إلى التأصيل الإسلامي للأبعاد الواقعية والرمزية في الدراسات الأخلاقية في الفكر الإسلامي،

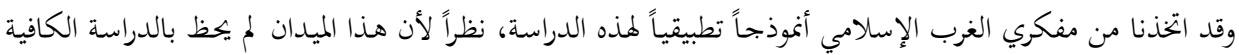

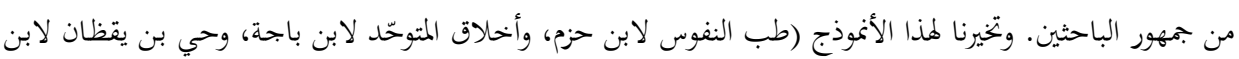

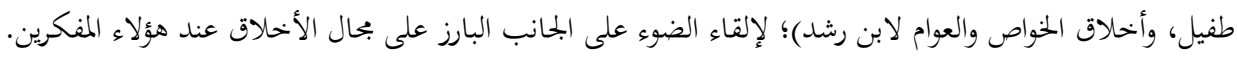

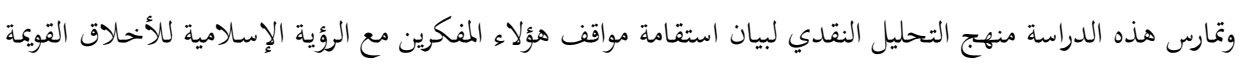
المستمدة من القرآن والسينة ومحدداتمما.

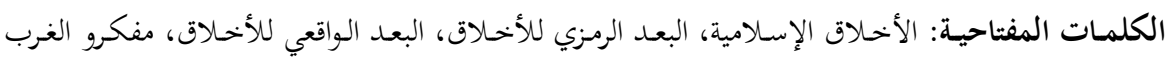

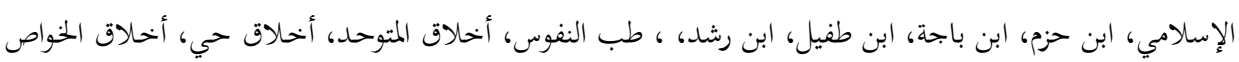

\section{Philosophical-Ethical Islamic Discourse between Realism and Symbolism: Scholars of Muslim Maghrib as an Example.}

\section{Abstract}

This study aims to establish an Islamic foundation for realistic and symbolic dimensions of ethical studies in Islamic thought. Scholars of Islamic Maghrib were not studied extensively in this regard. For this purpose, we have chosen Ibn Hazm's Tib AlNufus, Ibn Bajah's Akhlaq al-Mutawahhid, Ibn Tufayl's Hayy Ibn Yaqzan, and Ibn Rushd's (Averroes) Akhlaq Al-Khawass wa Al-'Awamm. We will shed some light on these outstanding thinkers in the field of Ethics, using critical-analytical methodology and Islamic worldview of Ethics founded on the Holy Quran and Prophetic Sunnah, to evaluate their contributions.

Key wards: Islamic ethics, Symbolic ethics, Realistic ethics, Muslim Scholars of the Maghrib, Ibn Hazm, Ibn Bajah, Ibn Tufayl, Ibn Rushd (Aversoes), Tib Al-Nufus, Akhlaq AlMutawwahid, Hayy Ibn Yaqzan, and Akhlaq Al-Khawass wa Al-'Awamm.

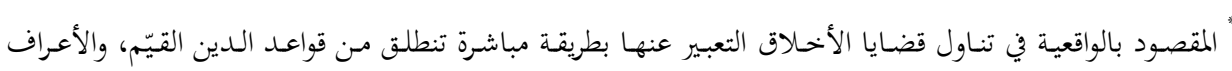

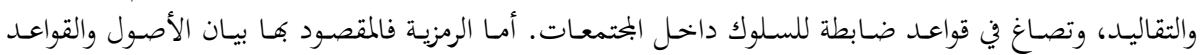

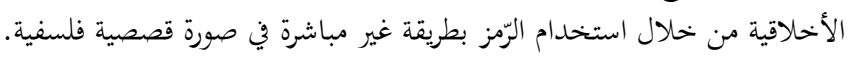

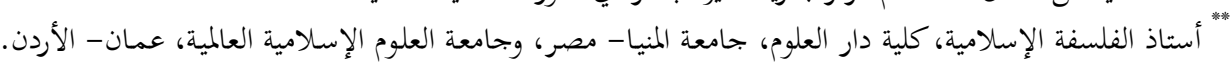

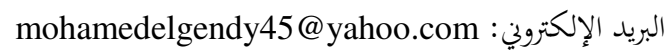

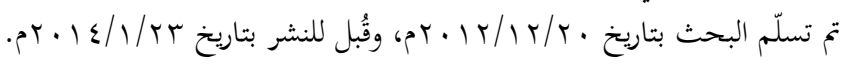


مقدمة:

لماكان الجانب (الواقعي، والرمزي) في دراسة الجحانب الأخلاقي في الفكر الفلسفي الإسـلامي يقتضي تحديد بحال تتحقق فيه مواصفات هذه الدراسـات ونطاقها البحثي، فتـد كان التوجّهـ إلى تطبيق هـذا الأنموذج في الدراسـات الأخحلاقيـة على مفكري الغـرب الإسلامي (المغرب والأندلس)؛ إذ لم تحظَ الدراسـات الأخلاقية فيه بالعناية الكافية مـن جمهـور البـاحثين، ولم تُفـرد لهـا دراسـات مسـتقلة تتنـاول الجموانـب الأخحلاقيـة بالتحليـل والدراسة. ولعل ذلك يرجع -من وجهه نظرنا- إلى أسباب عدة منها: أولاً: غلبة الطابع الرمزي على كتابات أبرز فلاسفة المغرب من أمثال ابن باجة (توفي

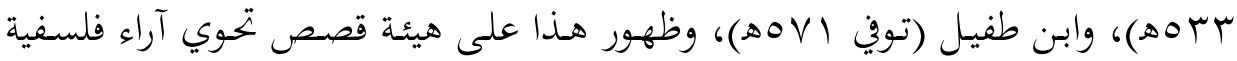

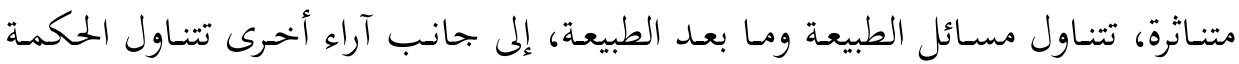
العملية، والنظرية، وقضايا الأخلاق، ووسائل تحقيق السعادة.

ثانياً: عدم إفراد بحال مستقل لدراسة الأخلاق على نهو تفصيلي عند معظم فلاسفة الغرب الإسلامي، ولا سيما ابن رشد (توفي 900ه) الذي بـث آراءه الأخلاقية في ثنايا

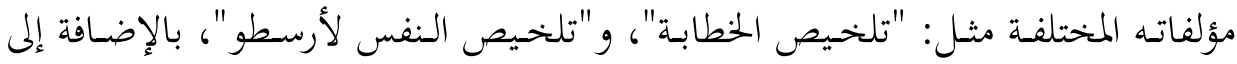
إشارات مقتضبة إلى قضايا أخلاقية في بعض مؤلفاته الأصيلة، مثل: "قافت التهافت"، و "فصل المقال"، و "الكشف عن مناهج الأدلة".

ثالثاً: شيوع عدد مـن الآراء الأخلاقية في كتابات الفقهاء، والصوفية من أمثال ابن

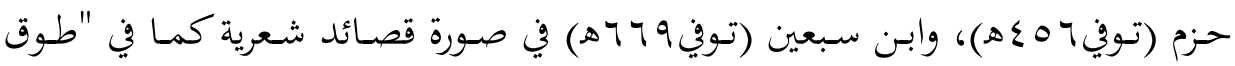

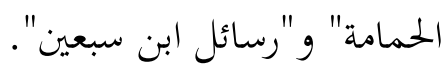

رابعاً: ضياع جانب كبير من مؤلفات فلاسفة المغرب؛ إذ لم يصلنا من مؤلفات "ابن باجة" سوى رسائله الإلهية التي اعتمدنا عليها بوصفها مصدراً رئيساً لفلسفته الأخلاقية، وكذلك لم تصلنا من كتب ابن طفيل سوى رسالة "حي بن يقظان". 


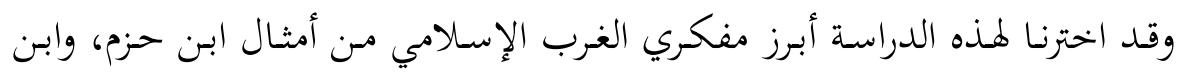

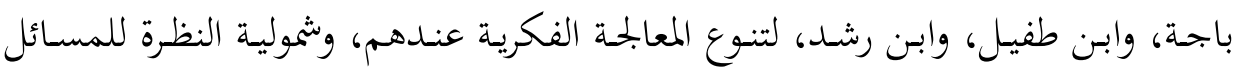

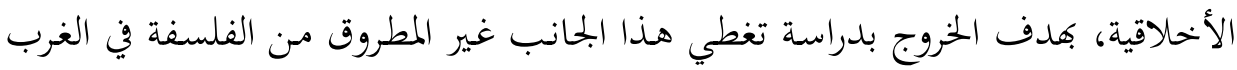
الإسلامي.

وقد قسمنا الدراسة إلى خمسة مباحث رئيسة؛ إذ عالج المبحث الأول معالم الحياة

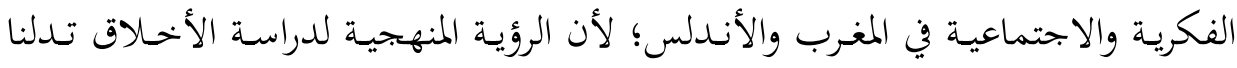

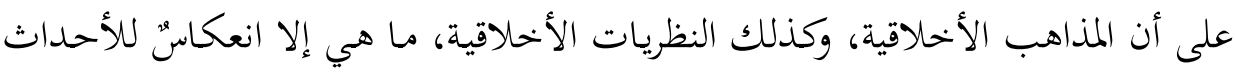

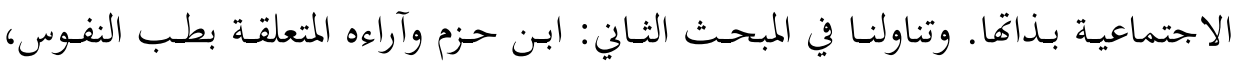

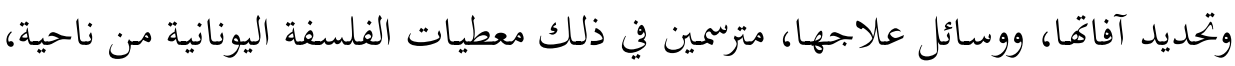

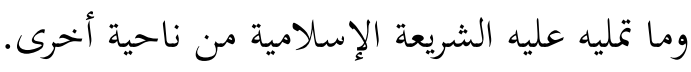

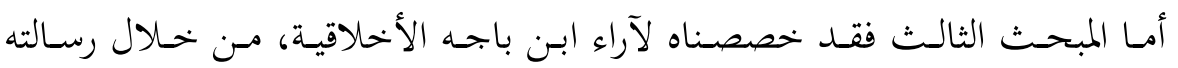

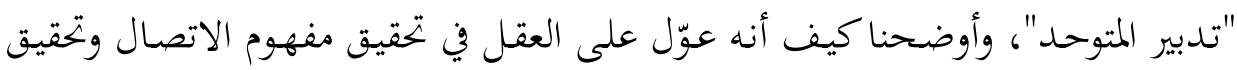

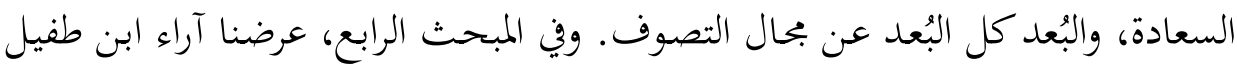

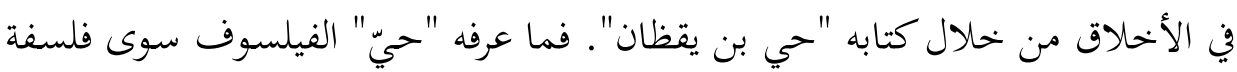

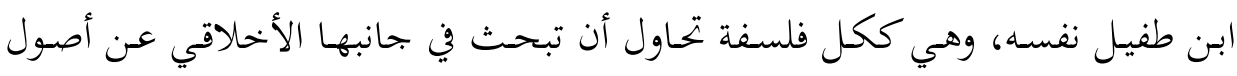

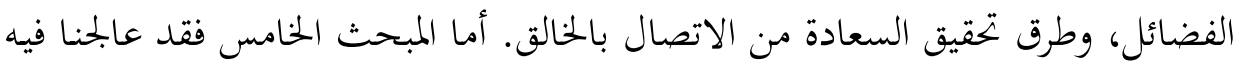

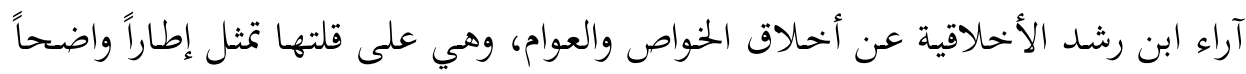

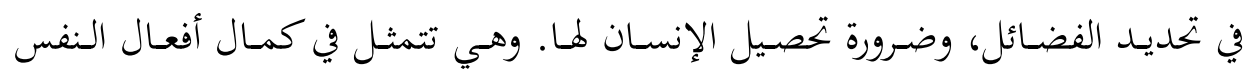
الإنسانية عن طريق قوة العقل العملي، وقوة العقل النظري.

\section{أولاً: معالم من الحياة الفكرية والاجتماعية في الغرب الإسلامي}

نتحدث في هذا المبحث عن الحياة الفكرية، والاجتماعية في الغرب الإسلامي. وقد ألد

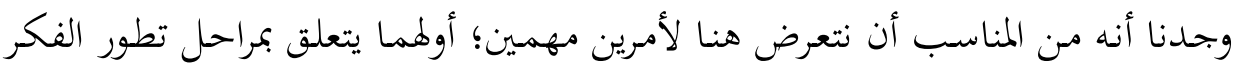


العلمي والفلسفي في الغرب الإسـلامي؛ وثانيهما يتنـاول مكانة الدراسـات الأخحلاقية في الفلسفة في الغرب الإسلامي.

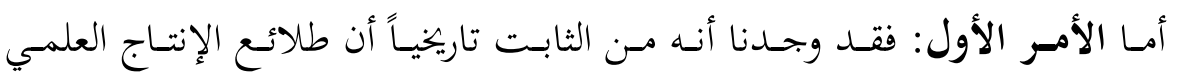

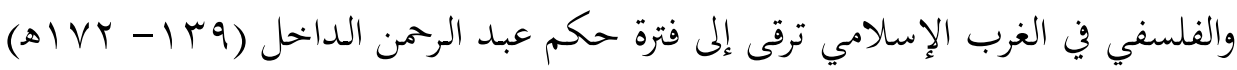

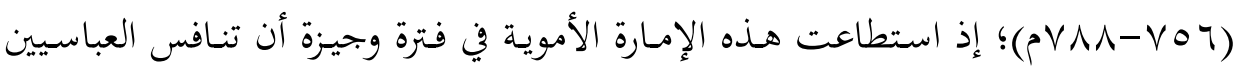
في المشـرق، ليس في الميـدان السياسـي فحسـب، بـل في الميـدان الثقـافي والفكـري أيضـاً. وهكذا "قُيّض للأنــلس أن تقـوم بـدور بـارز في تـاريخ الحضـارة العربيـة، وتصبح الجسـر الذي عبر عليه العلم والفلسفة إلى أوروبا الغربية في أواخر القرن السادس للهجرة الثاني

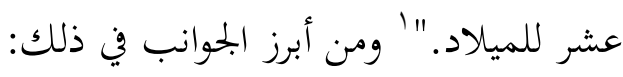

\section{ا ـ الجانب العلمي في الفلسفة في الغوب الإسلامي:}

يقول صاحب كتاب طبقات الأمه: "إن الاشتغال بالعلوم القديمة بدأ في عهد محمد

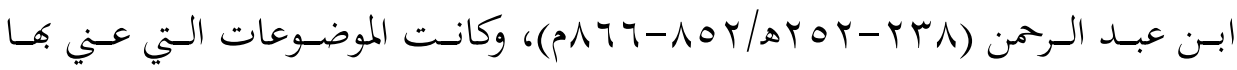
الأندلسيون آنذاكك مقصسورة على الطب والفلك، فضـلاً عن العلوم النقليـة مـن تفسير، وفقه، وحديث، إلا أن الإقبال على العلوم القديمة لم يلبث أن حظي بالتشجيع الرسمي،

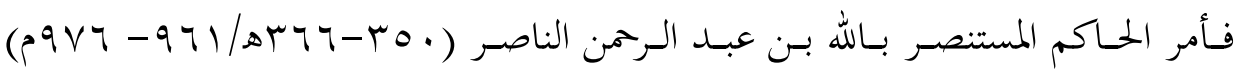
بجلـب الكتب العلميـة والفلسفية مـن المشـرق، حتى أصبحت قرطبة، عاصمة الأنـدلس تضاهي بجامعها، ومكتبتها بغداد عاصمة الخلافة العباسية." ومن أشهر علماء هذه الحقبة "مسلمة بن أحمد المحريطي" عالم الرياضيات، والفلك، وكذلك "أبو الحكمم عمرو الكرماني" الذي اشتغل بالمنطق والفلسفة، وبرز في الهندسة. ومـنهم كـذلك ابـن الجحلاب، وابسن القنـاري، وابـن حـزم، وابـن سـيده. ويشسير صـاعد

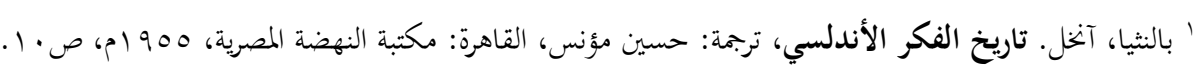

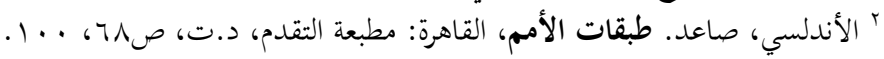


الأندلسي إلى أنه لم يبرز منهم في العلوم الطبيعية والإلهية إلا عبد الله بن النباس البجاني، وأبو عثمان البغنوش الطليطلي. ويتضح مّما سبق أن الفكر العلمي في هذه الفلسفة قد مرّ بثلاث مراحل: مرحلة الرياضيات، ثم مرحلة المنطق، وأخيراً مرحلة الفلسفة أنة الفحئ.

\section{Y ا أثر فلسفة المشرق في فلسفة الغرب الإسلامي:}

كان النتاج الفلسفي المشـرقي يصل تباعـاً إلى الأندلس، "واهتم كثير مـ الأمراء،

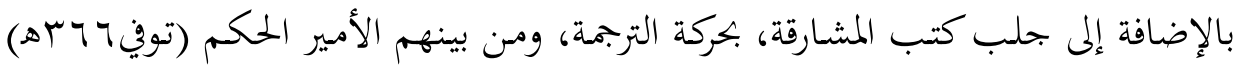

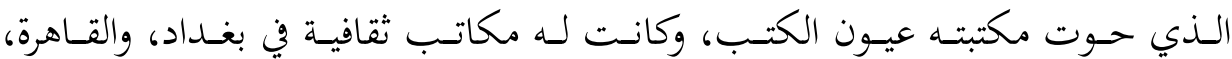

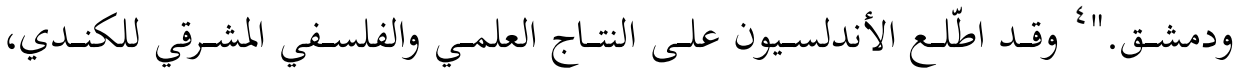

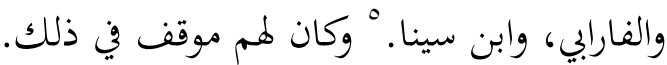

ويرى بعض الباحثين أن الفـارابي أكثر فلاسفة المشرق تأثيراً في الفلسفة العربية في

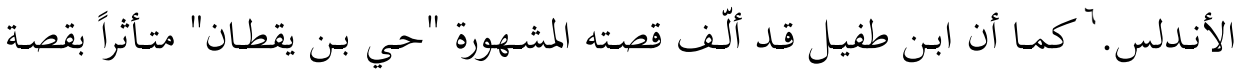

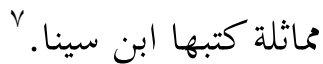

r. أسباب عرقلة نمو الحركة الفلسفية في الغرب الإسلامي:

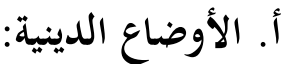

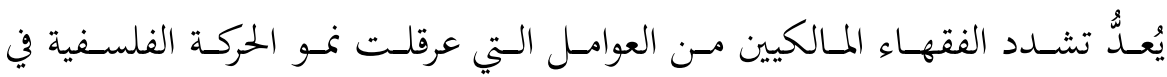

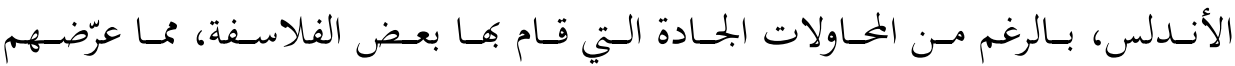

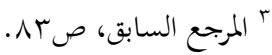

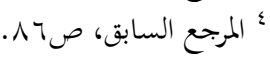

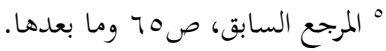

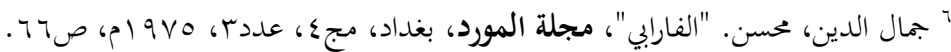

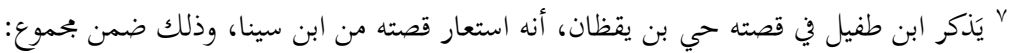

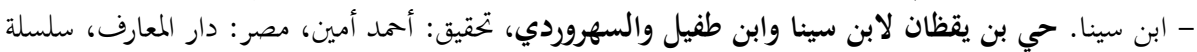


للملاحقة، وحرق ما يكتبون في الساحات العامة إرضاءً للعامة. وقد صوّر المقدسي ذلك بقوله: "أما في الأندلس... فهم يقولون لا نعرف إلا كتاب الله، وموطّاّ مالك، فإن ظهروا

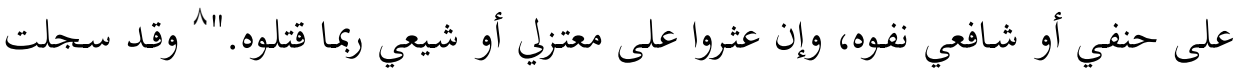

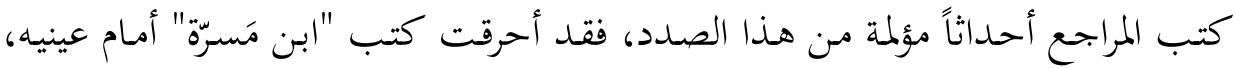

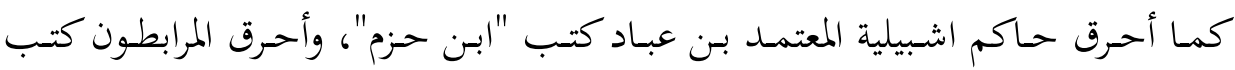

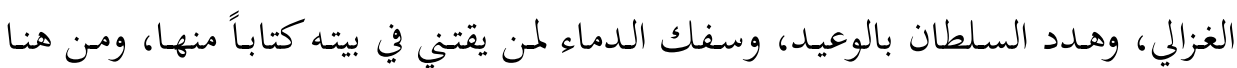
اضطر كثير من الفلاسفة والعلماء إلى الهجرة من بـاد الأندلس فراراً من سطوة الحكمى

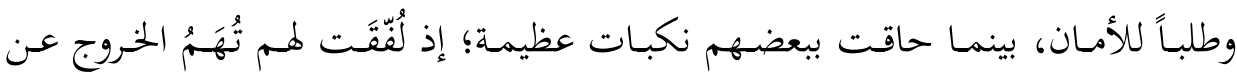
الدين، ومن بين هؤلاء ابن رشد.

\section{ب. الأوضاع السياسية والاجتماعية:}

ظهر إبـان حكـم الإمـارة والخلافـة في عهـد المـرابطين أمـراء رضـخوا لسـيطرة بعض الفقهاء، ورغبات العامة في محاربة الفكر الفلسفي، وأبطلوا الاجتهاد، وقمعوا التجديد، وأحرقوا كتب الغزالي، وعدّوا علم الكلام بدعة في الدين. وملا ضعفت أحوال المرابطين، ظهرت حركة جديدة على يد "حمد بن تومرت" الملقب بالمهاي، الذي أخذذ يعمل على نشر دعوته الجحيدة "وكان جلّ ما يدعو إليه علم الاعتقاد على طريقة الأشعرية." ·" "ولما تعاظم أمر الموحدين تغلّبوا على المرابطين، وأصبحت المغرب بما فيها الأندلس تحت إمرتم، وازدهر حكم الموحدين. وكان لبعض حكامهم ميل إلى الفلسفة وعلومها، وفي بلاطهم تألق بنم الفيلسوفين "ابن طفيل"، "وابن رشد"، فوصلا إلى مرتبة عالية، إلا أن ابن رشـد حاقت بـه نكبـة مثلمـا حلّت لفلاسفة مـن قبله على يـد الخليفـة الموحسدي

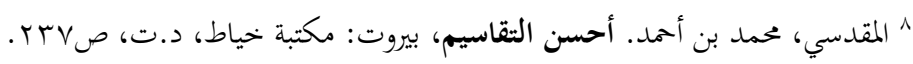

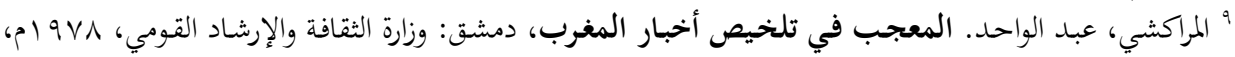

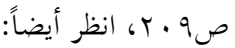

- Renan, Ernest. Averroes et l'Averroisme, in Oeuvres Completes de Ernest Renan, Paris: Ca1mann—Lévy, 1949, p.82. 


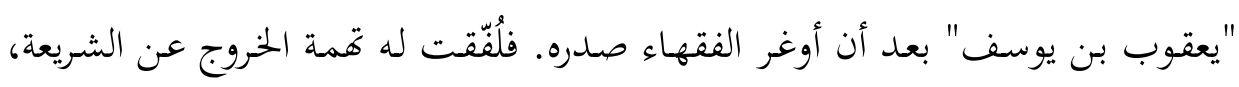

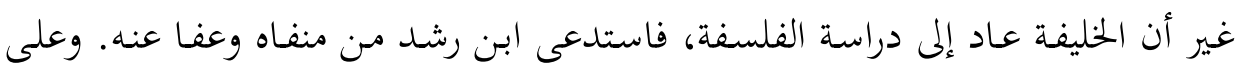

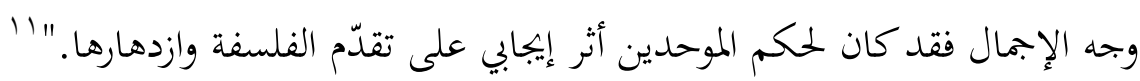
وأمسا الأمر الثاني: فهو متصل بمكانة الدراسات الأخلاقية في الفلسفة المغربية؛ إذ

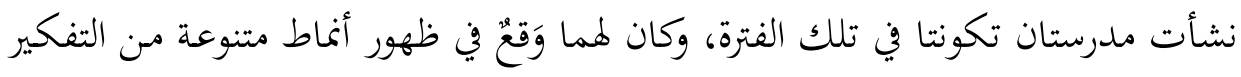

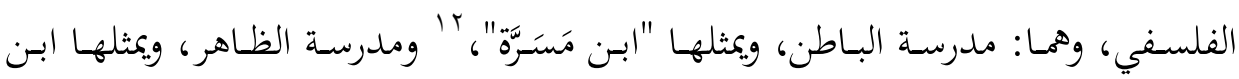

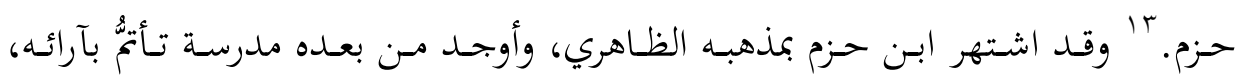

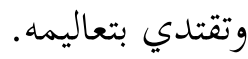

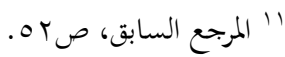

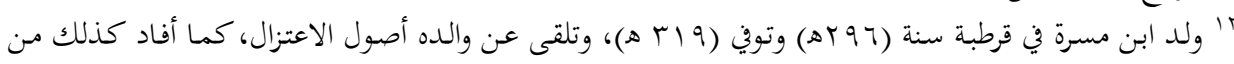

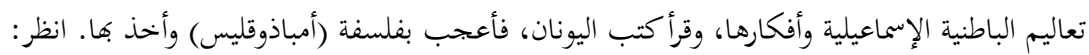

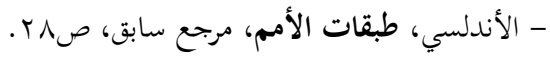

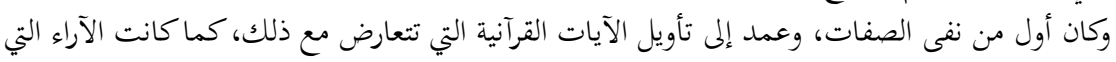

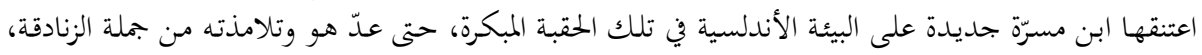

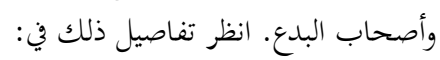

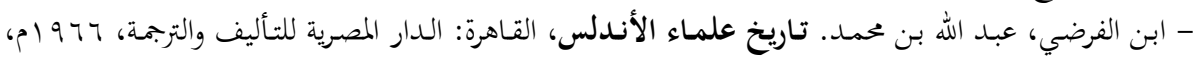

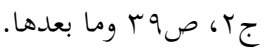

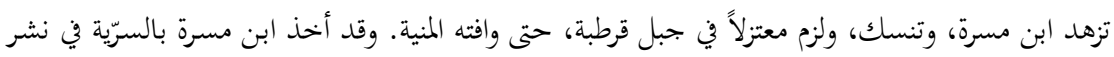
تعاليمه وتلقينها لأتباعه.

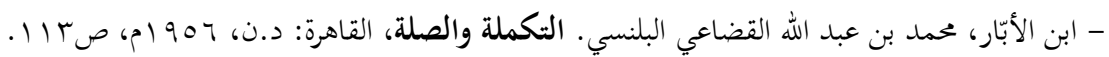

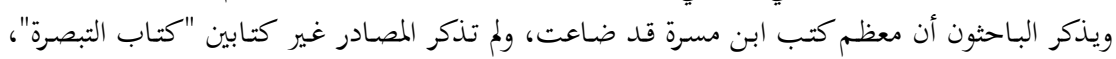

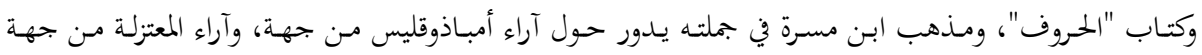
أخرى (ب)

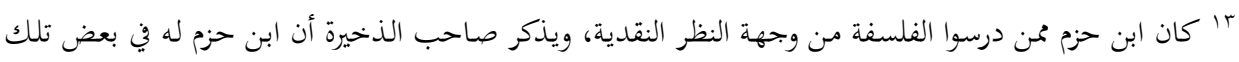

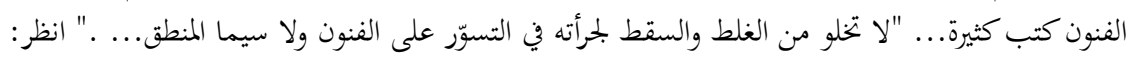

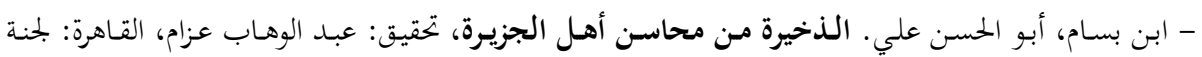

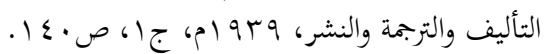

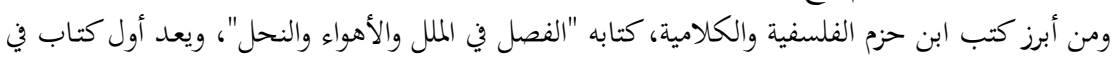

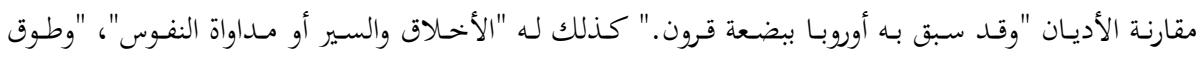

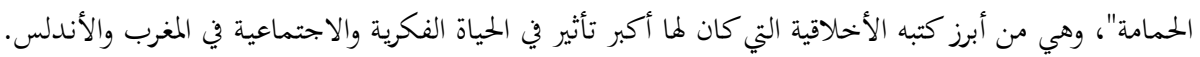




\section{ثانياً: ابن حزم الأندلسى وطب النفوس}

لم يهتم ابن حزم عُ بالفلسفة النظرية؛ لأن تلك الفلسفة تخالف مذهبه الظاهري. فلمـا عرف الفلسفة اقتصـر على الجانب العملي منها، وفي ذلك يقـول: "الفلسفة على

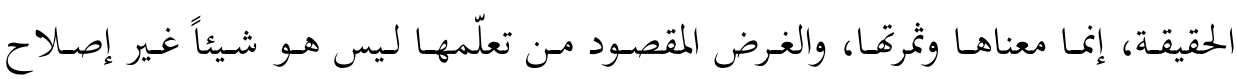
النفس، بـأن تستعمل في دنياهـا الفضـائل، وحسن السـيرة المؤديـة إلى سـلامتها في المعاد، وحسن السياسة للمنزل والرعية، وهذا نفسه لا غيره هو الغرض في الشريعة."17ا وأهـم كتـب الفلسـفة الأخلاقيـة عنــ ابـن حـزم - كمـا أشـرنا- همـا: رسـالته "طـوق الحمامـة في الألفـة والألافت"، وفيها درس ابـن حزم النفس الإنسانية فيما تحسبّ وتألف،

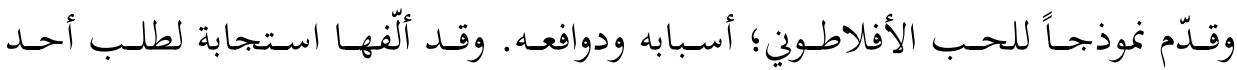
أصـدقائه، ولا نعلم على وجـه التحديـ زمـان كتابتها، غير أنه مـن المؤكد أهـا كتبـت بعد ولا سيما بعد انحراف الأخلاق العامة في عهد يوسف بن تاشفين في المجتمع المرابطي، وتفشي المفاسد والأمراض، الماض

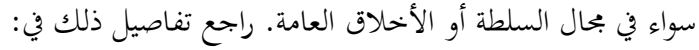

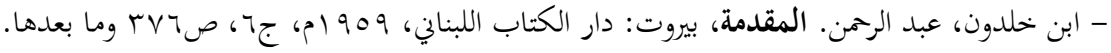

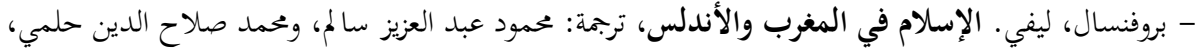

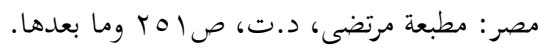

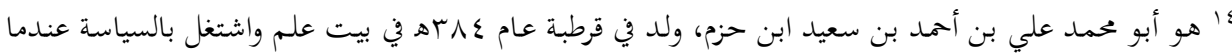

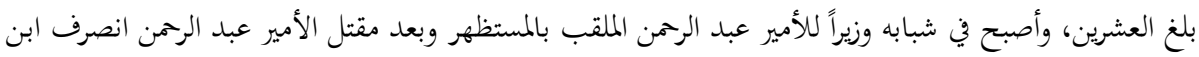

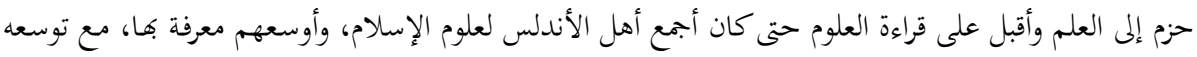

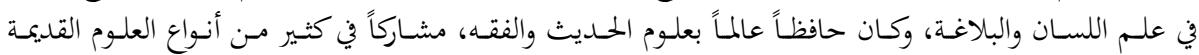
والفلسفة، وعني بعلم المنطق.

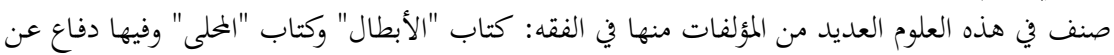

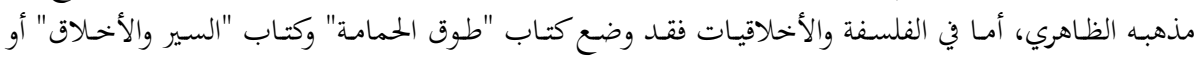

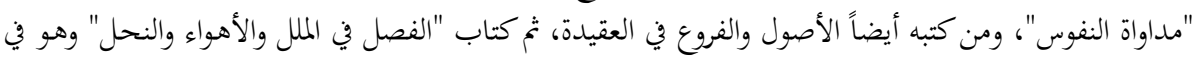

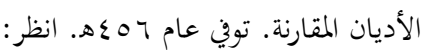

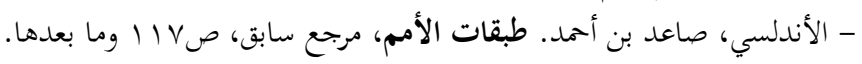

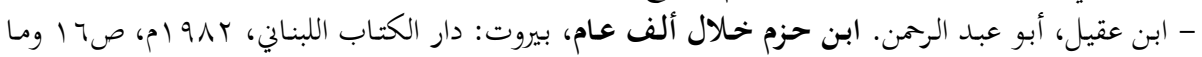
بعدها. •l يقوم المذهب الظاهري على الالتزام بالكتاب والسنة، والوقوف عند ظاهر نصوصها كما تدل عليه ألفاظ اللغة، مع عدم التعويل على القياس. 17 ابن حزم، علي بن أحمد. الفصل في الملل والأهواء والنحل، القاهرة: المطبعة الأدبية، VI VI اهـ، جال، صع 9. 


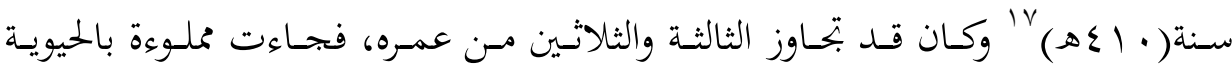
الناضجة التي بتحاوزت معه الشباب وغرارته. والرسالة تعالج في بحملها موضوع الحب، وحقيقته، ومراتبه، وأنواعه. والحبب عند ابن حزم هو محور الأخلاق الشخصية والاجتماعية، وعليه المعوّل في إصـاح النفوس، وقد اعتمـد ابن حزم فيها منهج الاستقراء والتتبُعُع، كما اعتمد أيضاً على ما وصل إليه مـن فلسفة اليونان، وبخاصة آراء أفلاطون^’' وأرسطو الأخلاقية، وقد مزج كلَّ هذا بالنصوص القرآنيـة، والشـواهد الإسـلامية. وتتّسـم الرسـالة بدقـة التنظيم، وحسـن التبويـب، وجمـال

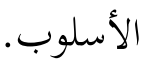

أمـاكتابه أو رسالته الثانية فهي الموسومة بـ"الأخهلاق والسير أو مداواة النفوس". 19 فعلى الرغم من صغر حجمها إلا أفا تحوي عدداً من الآراء اليونانية في مسائل الأخلاق المبنية على العقل، وقـد اعتمـد فيها على المقيـاس الخلقي الذي وضعه أرسطو للفضيلة

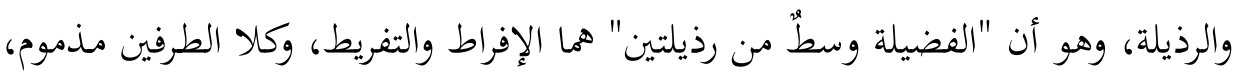
والفضيلة بينهما. ‘ُ ثم يستثنى مـن ذلك إفراط العقل في التقدير، والاحتياط، فلا يعدّه مــموماً، يقـول: "حاشـا العقـل، فإنسه لا إفـراط فيـه، الخطـأ في الحـزم خهير مـن الخطـأ في

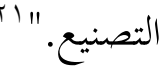

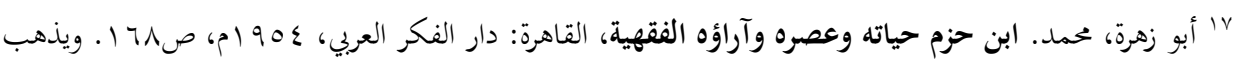

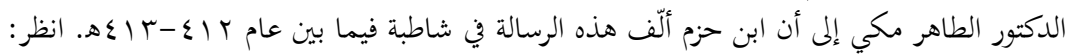

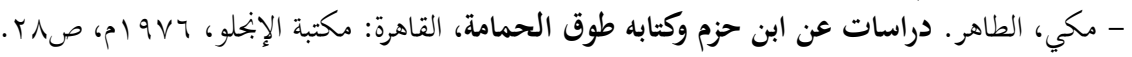

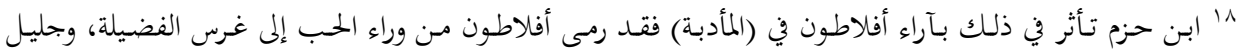

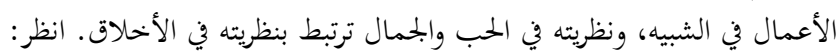

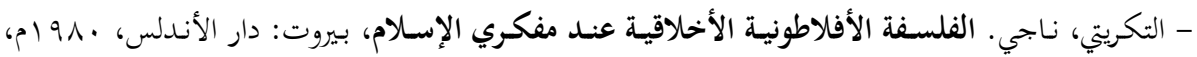
صمیr. 'ا والرسالة في بحملها نوع من المذكرات والحواطر التي دونت على مرّ الزمن، وكانت حصيلة التجربة المتدرجة، وأكثرها

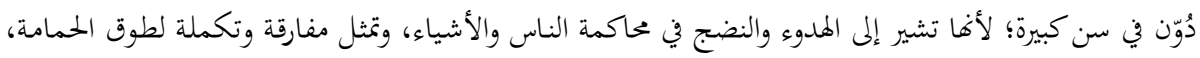

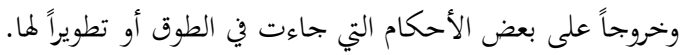

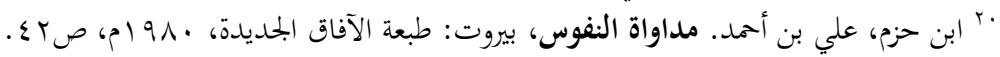

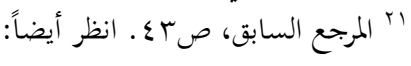


كذلك يُرجِع ابن حزم أصولَ الفضائل إلى أربع كما فعل أفلاطون، بَّ وإن اختلف

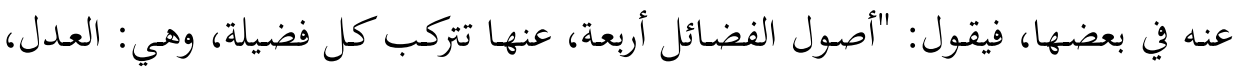

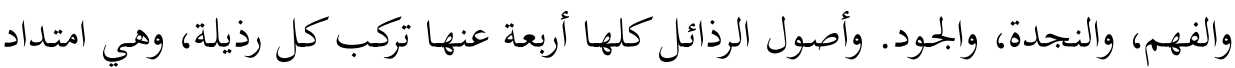

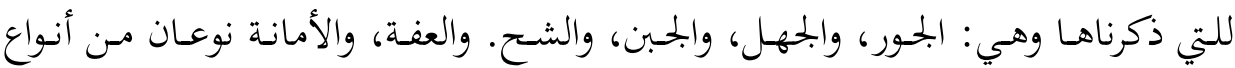

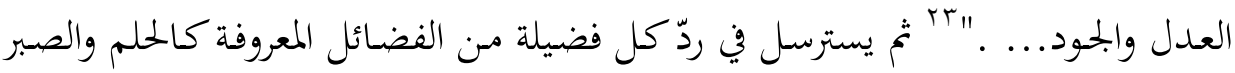
إلى هذه الأصول الأربعة.

ولا تخلو هـذه الرسـالة مـن سـرد للأخهالاق العمليـة التي كانـت معروفـة عنـــ الفـرس

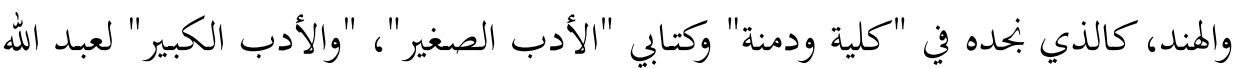
بن المقفع، الذي كانت كتاباته في الأخهاق خحاصة الفكر الفارسي المستمد مـن الفكر

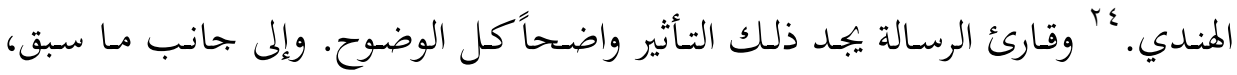

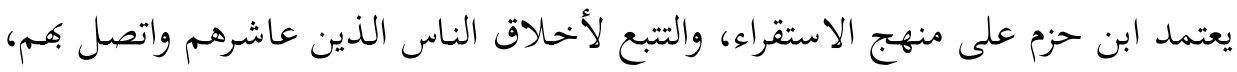

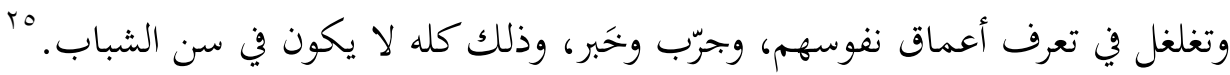
وعلى ذلك نقول: إن الرسالة قد استمدت عناصرها من ثلاثة مصادر أساسية؛ أولها الدراسات الفلسفية المبنية على العقل، وثانيها بحاربه الخاصة المبنية على الاستقراء والتتبع، وأما ثالثها فهو الشريعة الإسلامية.

- Ross, David. Aristotle: The Nicomachean Ethics, Complete English translation, London: Oxford University Press, 1925, p116.

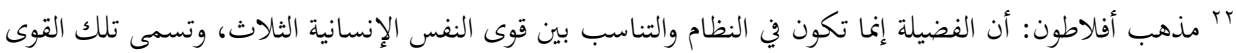

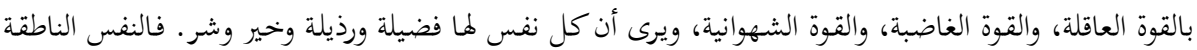

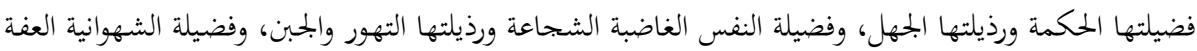

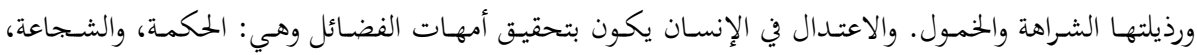

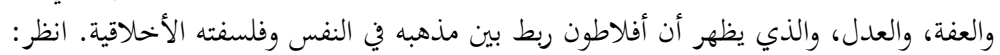
- Plato. Republic. Trans. Benjamin Jewett. Oxford: Clarendon Press, 1973, p 435.

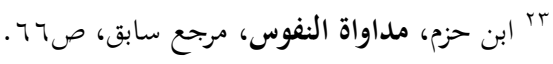

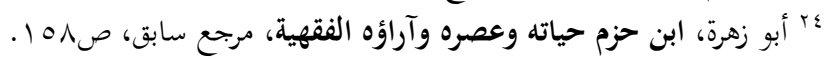

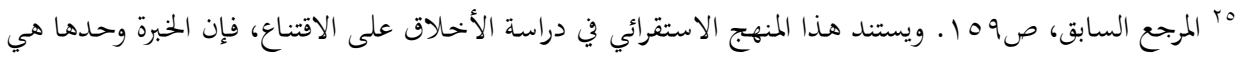

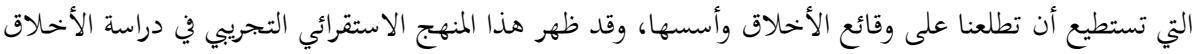

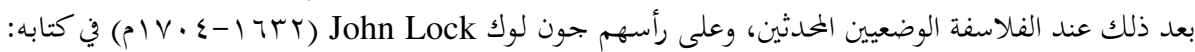

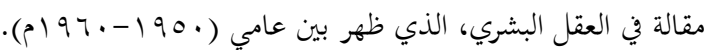




\section{1 ـ صور الفضائل والرذائل عند ابن حزم:}

\section{أ. الفضيلة وسالامة السلوك:}

إن الأخحلاق بقيمها، وقواعدها المؤدية إلى الفضيلة عند ابن حزم هي معيار سلامة منهج الإنسان في سلوكه، وهي التي تحدد مستقبلة الدنيوي والأخروي في أحد الابحاهين: السعادة أو الشقاء. ويُعرّف ابن حزم كُلّاً من الشقي والسعيد من الناس بقوله: "السعيد من أَنِست نفسه بالفضائل والطاعات، ونفرت من الرذائل والمعاصي، والشقي من أَنِست نفسه بالرذائل والمعاصي، ونفرت من الفضائل والطاعات."بr"

ونلاحظ في تعريف ابن حزم للسعيد والشقي، أنه لا يطمح في التحليق بعيداً عن

قواعد الفلسفة الخلقية في الإسلام، والمستمدة من الشرع، فعنده من أطاع الله، ورسوله في سلوكه، فقـد سـار في طريق الفضـائل وفـاز بالسعادة، ومـن عصى وجحـــ أَمْرَ الله تعالى يكون قد جلب الشقاء لنفسه وظلمها. فمن تنازعته أهواءُه ورغباته الحسية المشتركة مع سائر المخلوقات، انخطّ عن مكانته السـامية. ومسن نَشَد الحلكمة في الاعتمـاد على قوة الإدراك والنطق، التي ميّزه الله تعالى بهـا عـن هـا الطريق فقــ ينجـو، وتتحقـق غايته في

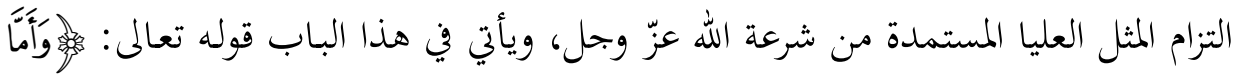

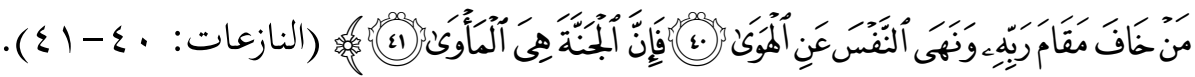
وعن هذا الإنسان يقول ابن حزم: إنه "جامع لكل فضيلة، وكل سلوك حسن؛ لأنه هُى النفس عن الهوى، وردعها عن الطبع الغضبي، وعن الطبع الشهواني؛ ولأن كَّلَّ منها واقع تحت موجـب الهوى، فلم يبق إلا استعمال النفس للنطق الموضوع فيها، الذي بـه

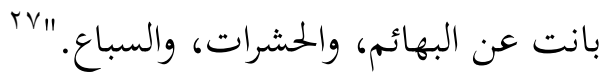

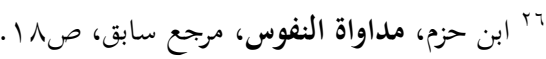

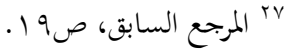




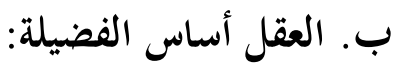

حذا ابن حزم حذو سقراط، فقد قرر أن القوة العاقلة يجب أن تشبع بتحصيل المعرفة

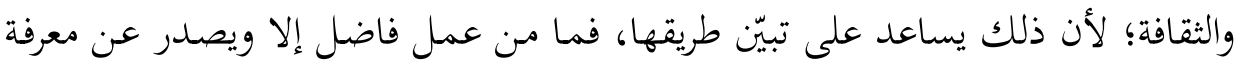

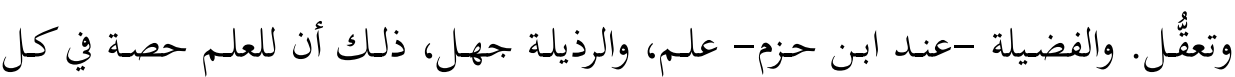

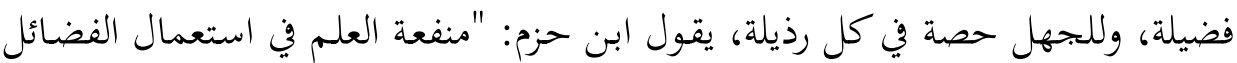

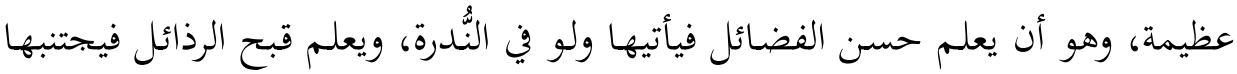

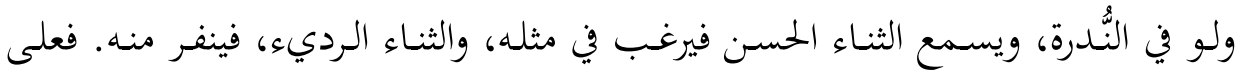

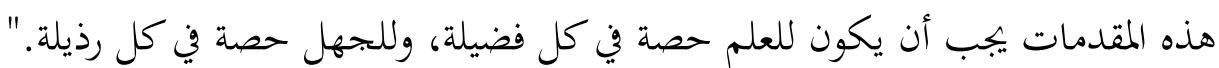

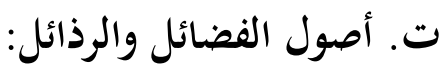

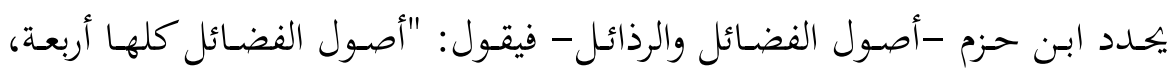

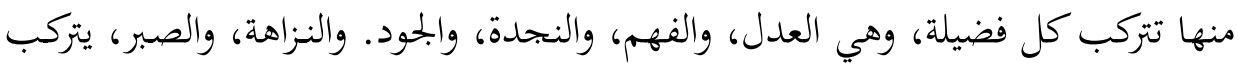

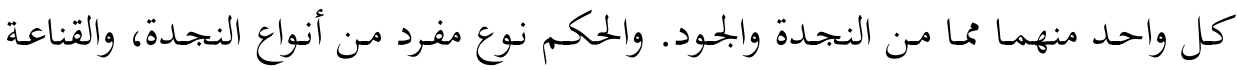

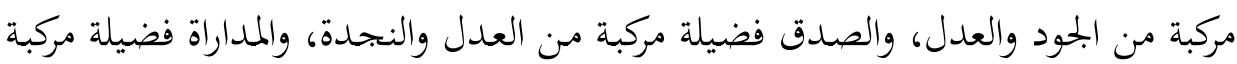

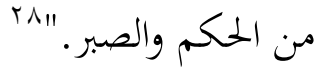

أما أصول الرذائل، فيحددها ابن حزم في أربعة هي: الجور، والجهل، والجمبن، والشحت.

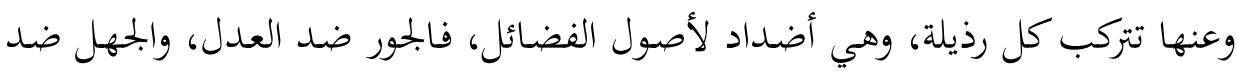
الفهم، والجبن ضد النجدة، والشح ضد ردئل الجمود.

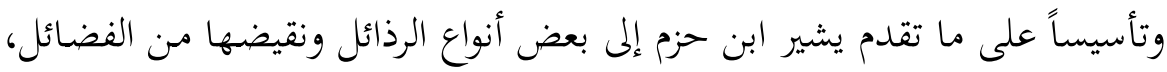

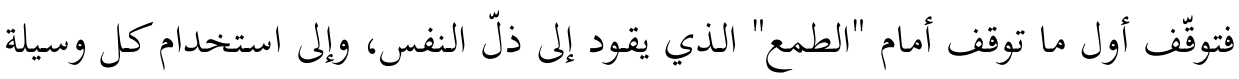

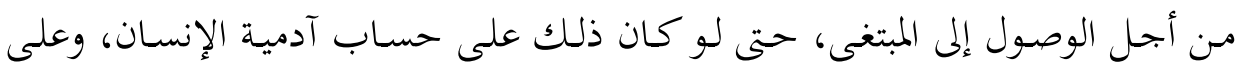

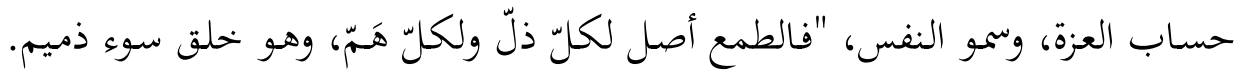

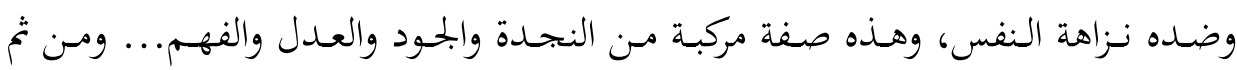

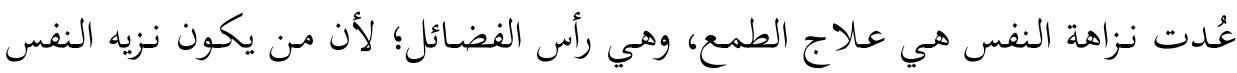
^^ ابن حزم، مداواة النفوس، مرجع سابق، صله-10 ه. وإلى مثل هذا التقسيم ذهب مسكويه في تحذيب الأخلاق. 
يكون قد فهم معاني الفضيلة وحارب مكان مَن طمع في نفسه، فالإنسان الفاضل هو

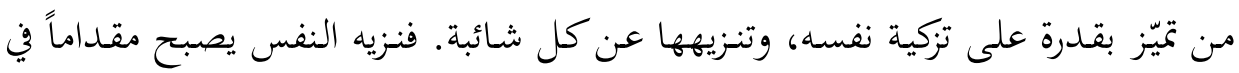

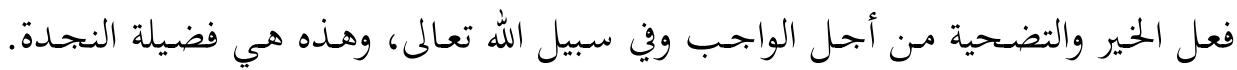

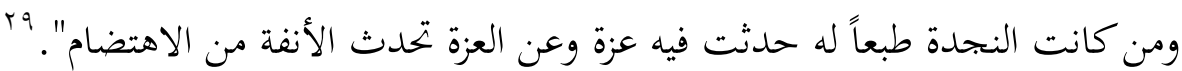

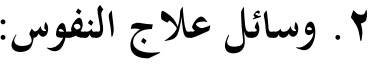

يرى ابن حزم أن صـاح النفوس، وعـلاج عيوبهـا أجدى وأنفع مـن مـاواة الجسـد،

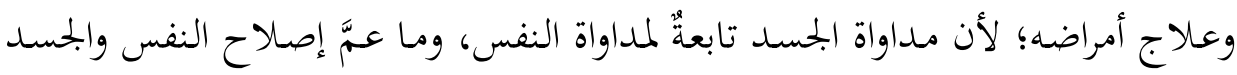

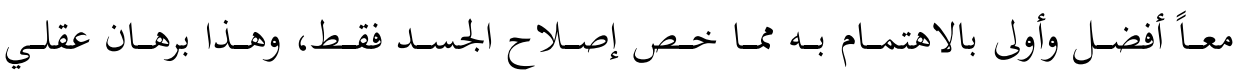

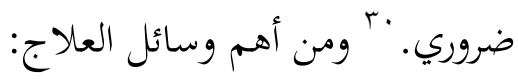

\section{أ. اتّباع ما قالت به الأنبياء:}

يتخذ ابن حزم من شخصية الرسول عليه الصلاة والسلام -على وجه الخصوصمثنلاً أعلى ونبراسـاً هاديـاً، لـذلك يقول: "مـن أراد خهير الآخـرة، وحكمة الدنيا، وعـل السـيرة، والاحتـواء على محاسـن الأخـالاق كلهـا، واسـتحقاق الفضـائل بأسـرها، فليقتـــ بمحمد رسول الله عليه الصحلاة والسلام، وليستعمل أخلاقه وسيره مـا أمكنه، أعانـا الله

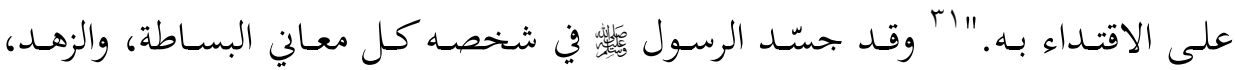
والتواضع التي ينبغي أن يقتدي بها كلهُ من يريد علاج أمراض نفسه ورذائلها. بَّاء

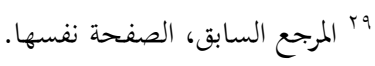

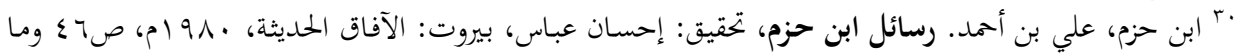

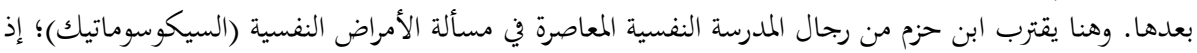

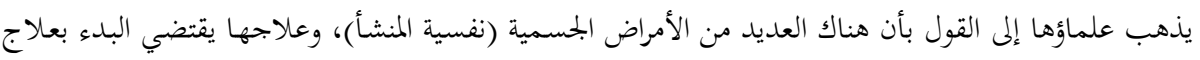

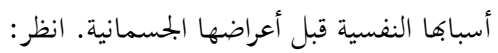

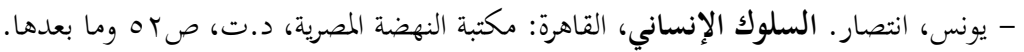

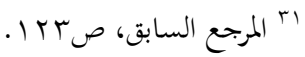

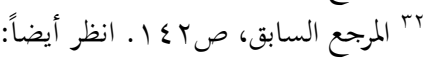

- Donaldson, Dwight M. Studies on Muslim Ethics, London: SPCK, 1963, p. 194 


\section{ب. رياضة النَّف، واتباع النصح، والوعظ:}

رياضة الأنفس عند ابن حزم أصعب من رياضة الأسد؛ لأن الأسود إذا سجنت في

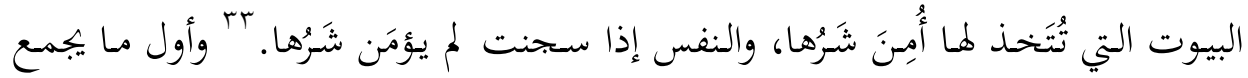

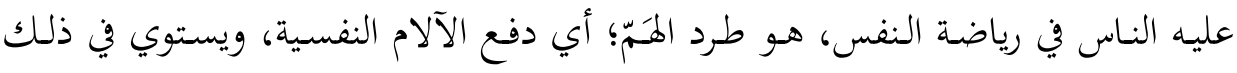

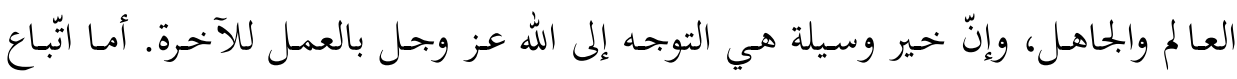

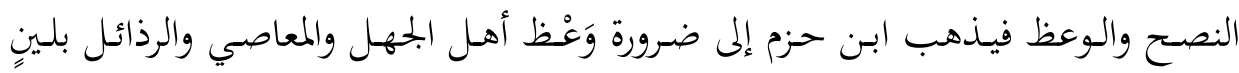

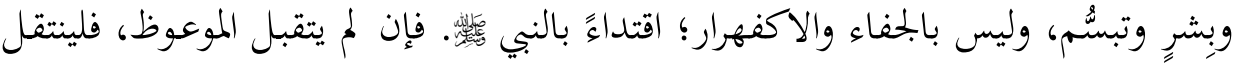

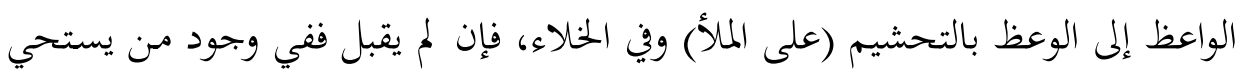
منه الموعوظ؛ لأن هذا هو أدب الله تعالى في أمره بالقول واللين.

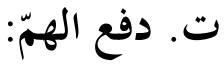

ويرى ابن حزم أن مقياس دَفْعَ الهمّ، وطلب ما عند الله هو مقياسٌ أساس في معالجة

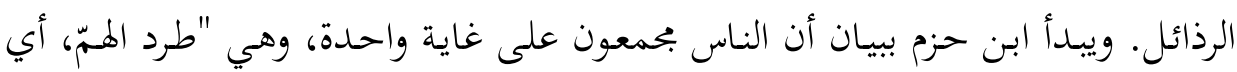

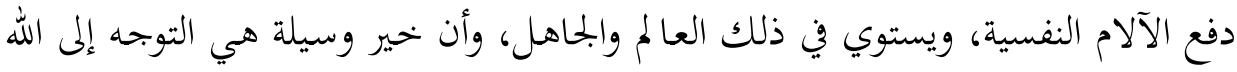

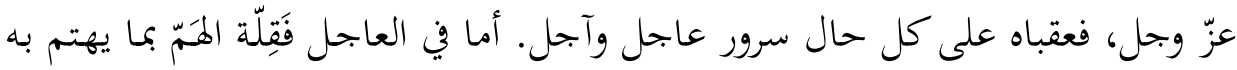

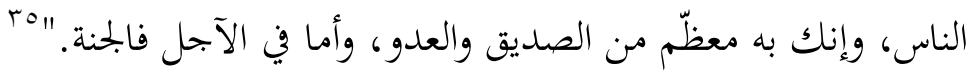

ويحدد ابن حزم أصناف الناس في دَفْعَ الهمّم فيقول: "إنما طَلَبَ المالَ طلابُه؛ ليطردوا

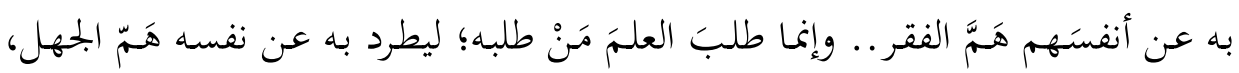

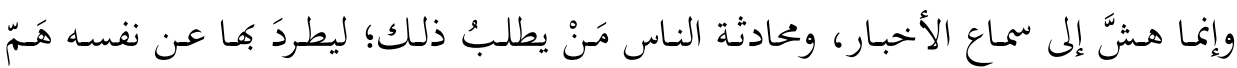
التومُّد، ومغيب أحوال العالم عنه."

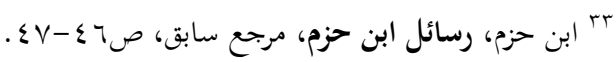

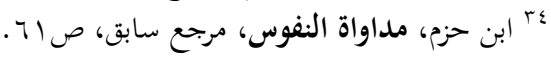

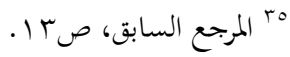

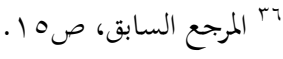




\section{ث. سلوك طريق الحق والثبات عليه (الفكر والعمل):}

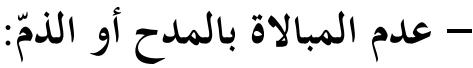

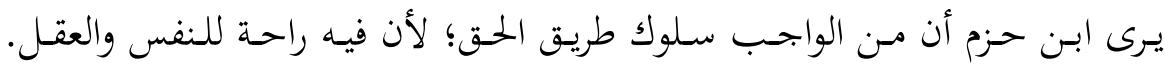

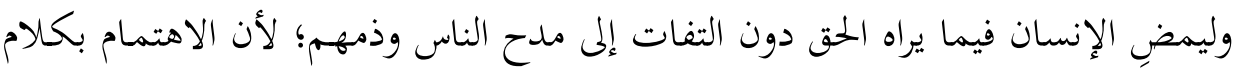

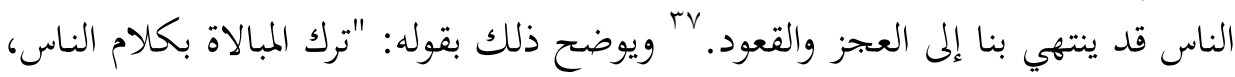

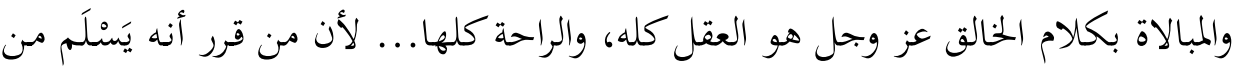

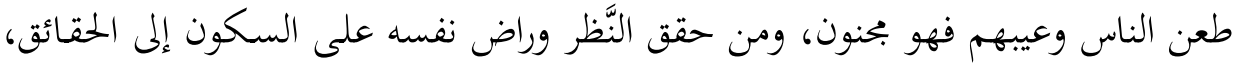

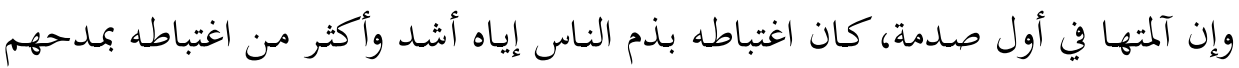

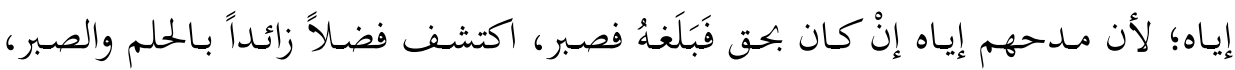

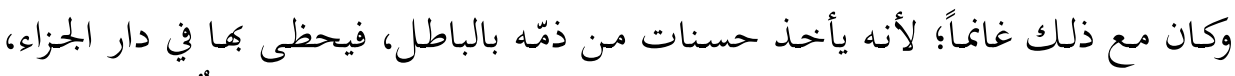

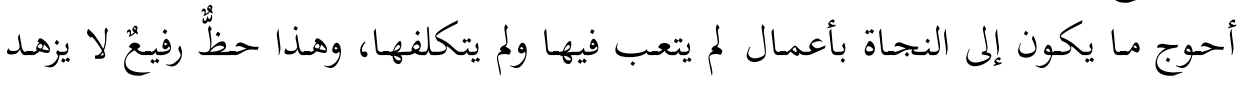

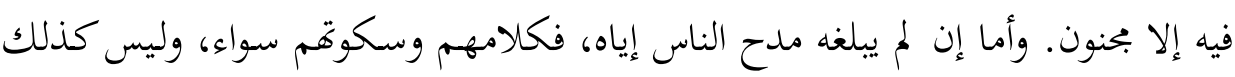

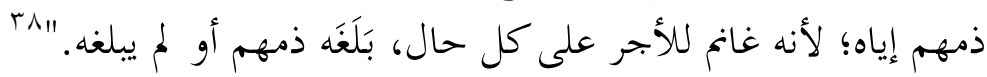

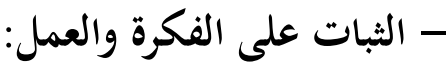

يقـول ابـن حزم في ذلك "الثبات على صحة العقده، والثبـات الذـي هـو اللجـاج

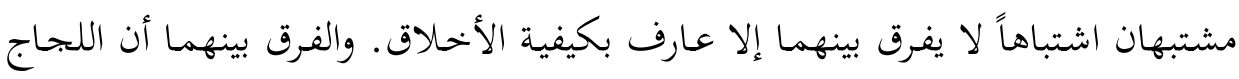

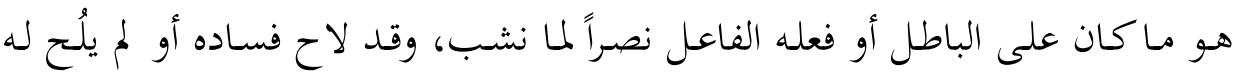

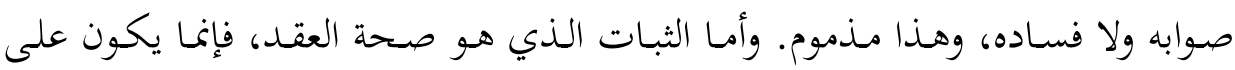

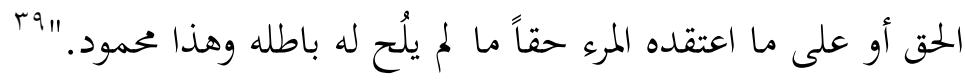

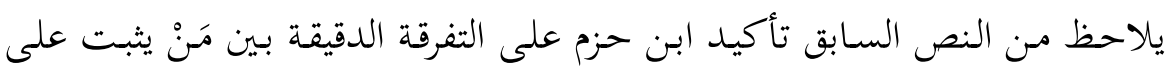

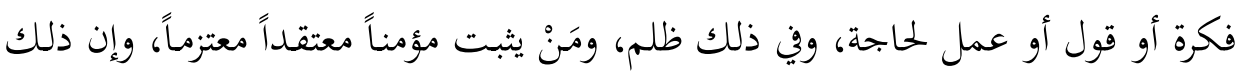

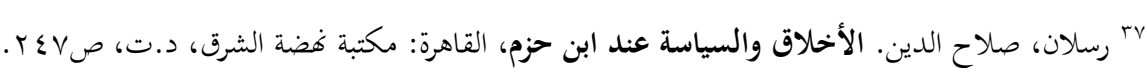

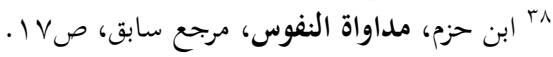

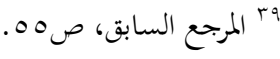


ثابت، وما عـداه نزعات مضطربة غير ثابتة. وهنا نرى دقة ابن حزم المتناهية في التفرقة بين مَنْ يثبت على فكرة باطلة، ومَنْ يثبت مؤمناً على الحثث، ومدافعاً عنه.

\section{ج. في التدين والاستخفاف بالدين:}

يدعو ابن حزم إلى الثقة بالمتدين ولو كان متديناً بغير الإسلام، ويدعو إلى عدم الثقة بغير المتدين ولو كان مـن المسلمين. وفي ذلك يقول: "ثق بالمتـدين، وإن كان على غير دينك، ولا تثق بالمستخِف وإن أظهر أنه على دينك، فمن استخفّ بحرمات الله تعالى، فلا تأمنه على شيء تشفق عليه." •؛

وهكذا يقـرر ابن حزم أن الاستخفاف انخلالع مـن حكـم العقل والدين معاً بفقـد

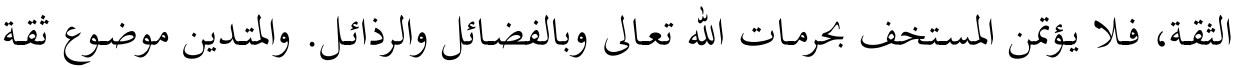

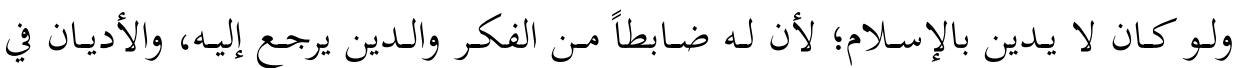
جملتها تحث على الأمانة، وتنهى عن الخيانة.

\section{ب. الاستعانة بالمنطق من تحصيل السعادة:}

اتخذ ابن حزم من المنطق وسيلة لمواجهة النكبات والمحن التي تعرّض لها في حياته، وبه كان يداوى على تململ المتحيزين له والمتتلمذين عليه، وفي ذلك يقول: "على العاقل أن

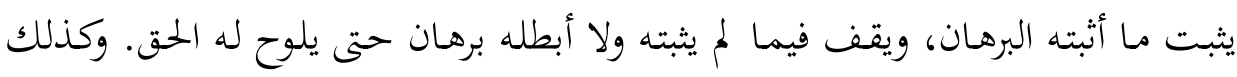
ليس علينـا قسـر النفـوس إلى الإقرار بـه، وقطع الألسـنة عـن المعارضـة الصـحيحة لعـدم

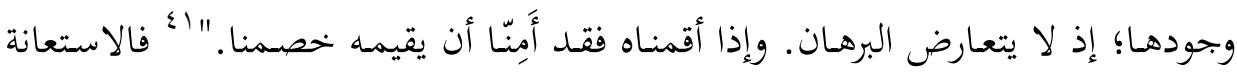
بـالمنطق في بحابهـة الخصـوم سيؤدي إلى شعور بالسعادة، وإلى نعيم نفسي لا يدركه غير الفئـة المختـارة مـن بني آدم، لا سيما إذا واكَبْتهه خصـال قلّ أن تتوفر لعامـة النـاس، مثل التخلي عن الغلَبـة في طلب الحـق، والخضوع للحق والقبول بـه حين ينكشف للنفس،

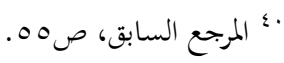

اء ابن حزم، علي بن أحمد. التقريب لحدد المنطق، تحقيق: إحسان عباس، بيروت: دار الكتاب اللبناني، 909 (م)، 
وعدم الاستيحاش مع الحق إلى أحد، واللامبالاة بكثرة الخصوم، وتعظيم الناس إياهم،

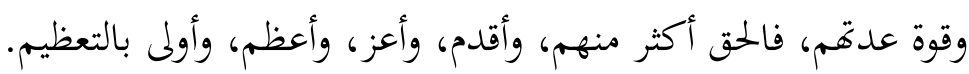

أما عن طبيعة العلاج المستمد من المنطق، فهو دواء (ارستقراطي) لا يتاح إلا لفئة

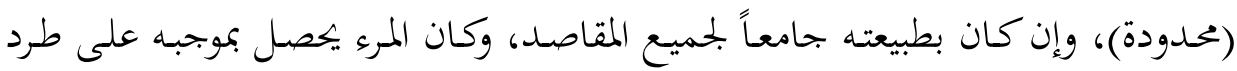

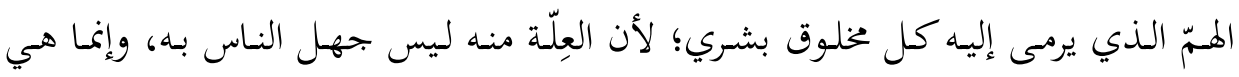
قدرقم على تحصيله، تم صلاحه لكل مريض.

ولعل السبب في محدودية المنطق في العلاج يرجع إلى داء استشرى في الناس، وهو

الانحلال الذي لا ينجح فيه منطق، ولا يردع الناس عن مسالكهم معـه "صحة رأي".

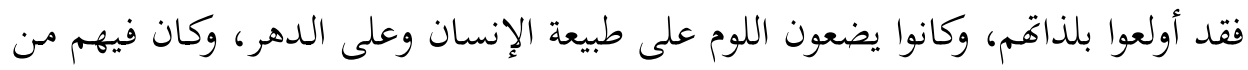

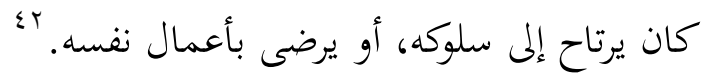

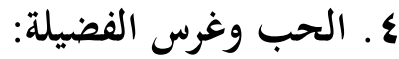

اتخذ ابن حزم من الحبّ وسيلة لغرس الفضيلة عند المحبين، لتسمو طبائعهم، ويبتعدوا

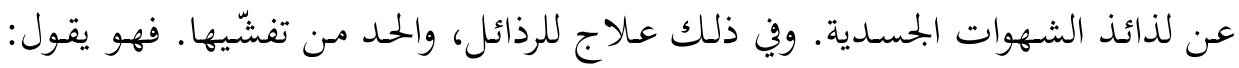

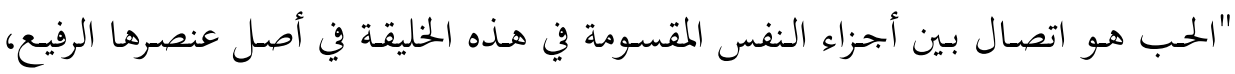

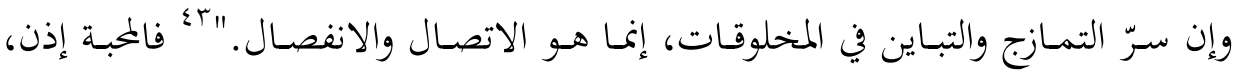
عند ابن حزم لا تقوم بين متنافرين أو متضادين، بل تقوم بين المتصلين المتشابهين. والشبيه عند ابن حزم يسعى وراء شبيهه، والحب في جملته هو اتحاد روحي، وامتزاج

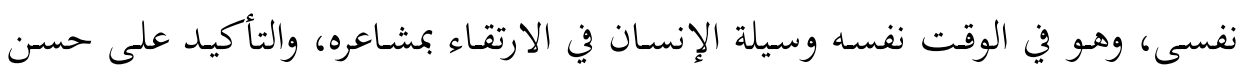

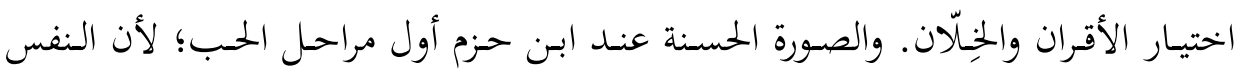

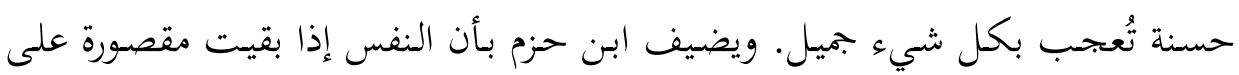

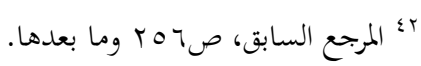

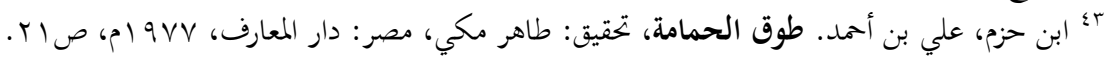


الصـورة الحسـنة فهـذه هي الشهوة، وإذا ميّزت وراء الصـور شيئاً مـن أشـكالها، اتصّلت

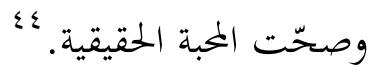

وعن مراتب الحب، وأنواعه يقول: "علمنا أن الحب ضروب، فأفضلها محبة المتحابين في الله عز وجل، وإمـا الاجتهاد في العمل، وإمـا الاتفاق في أصل النّحلة والمذهب، وإمـا لفضل علم يمنحه الإنسان، ثم محبة القرابة، ومحبة الألفة والاشتراك في المطالب، ومحبة البِّر

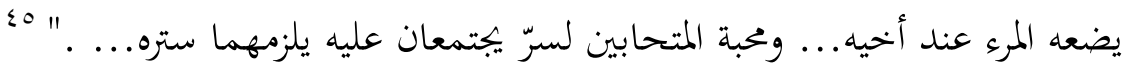
وعلى مـدى أبواب الرسـالة يـدعو ابـن حزر إلى تأصـيل الفضـيلة مـن خهلال الحـب

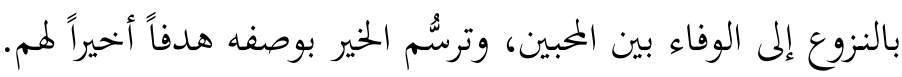
ويسوق ابـن حزم عـدداً مـن الأمثلـة على التفرقـة بـين الحـبـ والشـهوة، بـ ويــى أن التفرقة بينها كالتفرقة بين الظاهر والبـاطن. والشهوة علاقة جسـدية وهـو حـبّ الصـورة الحسنة، أما الحب فهو اتصال النفس، ويكون حين تميز النفس شيئاً وراء الصورة الحسنة.

ثالثاً: ابن باجة وأخحلاق المتوحِّد وإذا ما انتقلنا إلى ابن باجه \؛ بحد أنه يحتل مكانة كبيرة في فلسفة الغرب الإسلامي، على الـرغم مـن قصـر حياتـه، فهـو أول مـن وقـف في المغـرب والأنـدلس على فلسـفة

$$
\begin{aligned}
& \text { ؛؛ المرجع السابق، ص آ وما بعدها. }
\end{aligned}
$$

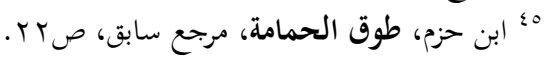

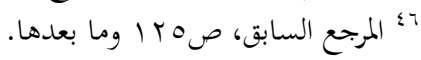

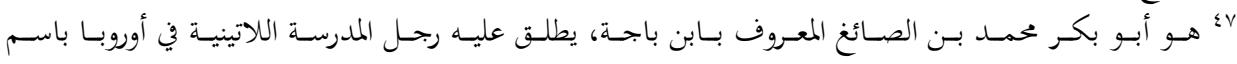

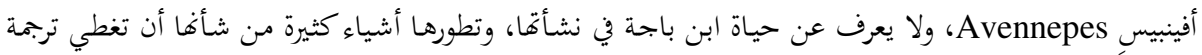

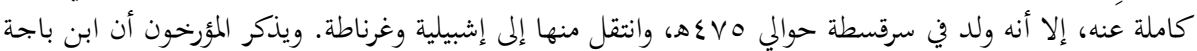

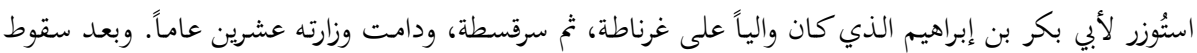

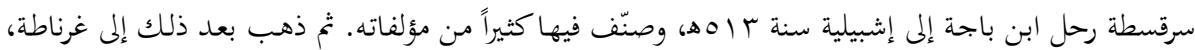

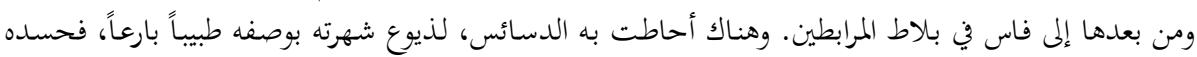

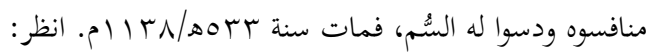

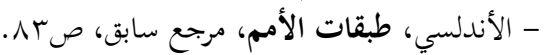




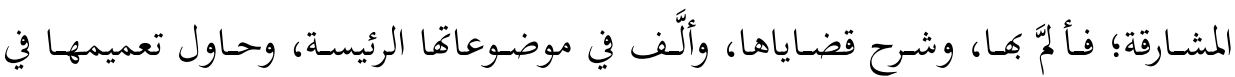

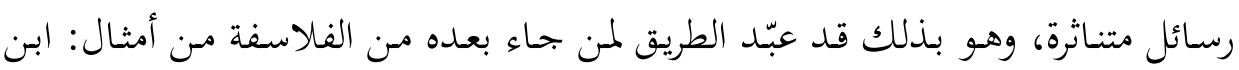

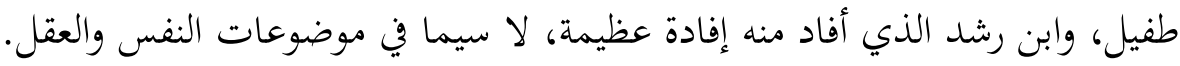
ومن أبرز مصنفات ابن باجـة الفلسفية، رسالة الوداع التي كتبها لأحسد أصدائه

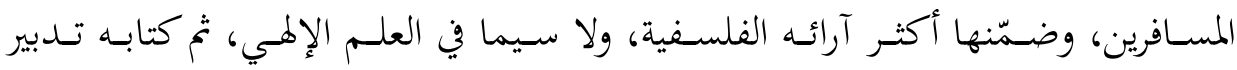

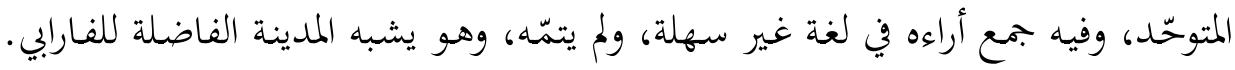

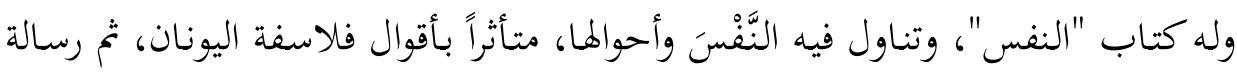

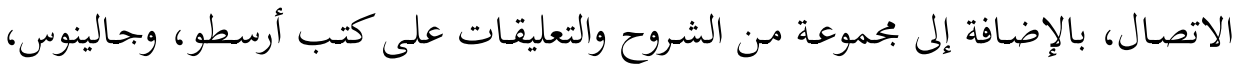

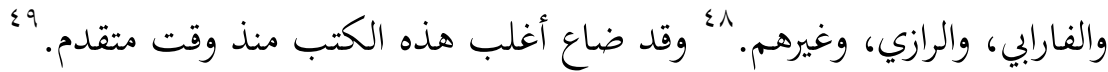
ومعظم مـا ذكره ابن باجة في فلسفته الأخلاقية موجود في كتابه أو رسالته "تدبير

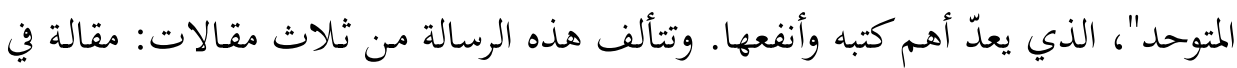

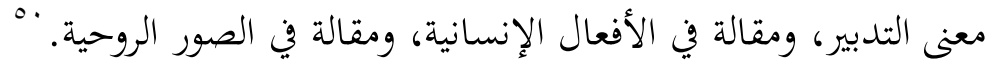
معنى التدبير: يتناول ابن حزم معنى التدبير على أنخاء عدة: الأول: تدبير الإله للعالم... وهو التدبير المطلق، والثاني: تدبير المدن، والثالث: تدبير

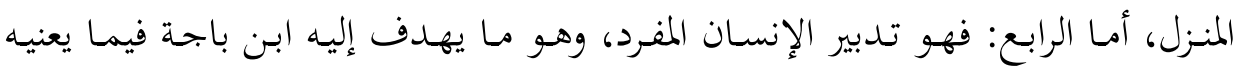

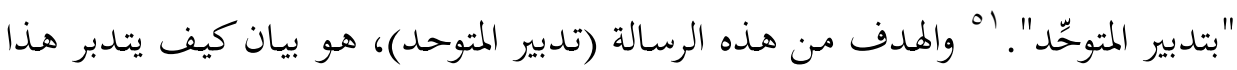

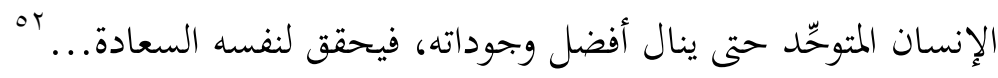

^؛ يرجع الفضل في الاحتفاظ بنص هذا الكتاب إلى الفيلسوف موسى النربوني، ويظهر الكتاب في نسختين خطيتين:

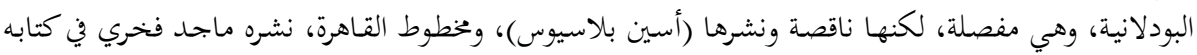

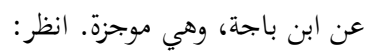

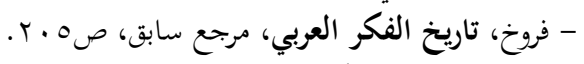

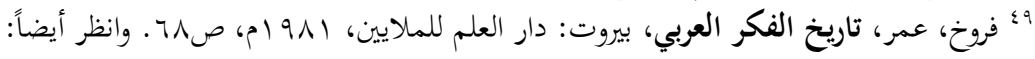

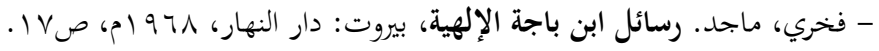

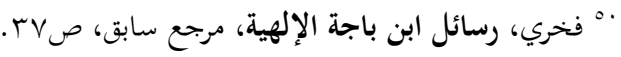

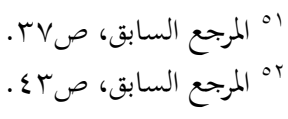


أمـا الفعـل الإنسـاني: فيذهب ابـن باجـة إلى النظر للأفعـال الإنسـانية النابتـة عـن "تدبير" بأفها تتصف بالروية والتعقّل، وهي الأفعال التي يمكن أن نطلق على كل فعل منها بأنه فعل إنساين. وتنقسم الأفعال الإنسانية عند ابن باجة إلى أصناف عدة: الأول: أفعال تصدر عن طبيعة الإنسان المادية (الجسمانية) كالسقوط إلى أسفل، وهي أفعال اضطرارية، ولا يمكن أن تكون موضوعاً للتدبير. والثاني: أفعال راجعة إلى طبيعة الإنسان الحيوانية، وهي في هذه الحالة أفعال غريزية لا تكون موضوعاً للتدبير.

الثالث: أفعال تنسب إلى الإنسان بوصفه كائناً عـاقلاً، وهي إمـا أفعال تصدر من العقل مباشرة أو أفعال تصدر عن الوحي والإلمام.

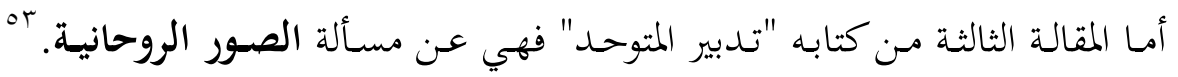
ويكصر ابـن باجـة هـذه الصـورة الروحية التي تقع داخل دائرة الفعل الإنسـاني في مقاصد

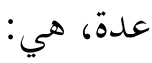
- الحس المشترك، والمخيلة، والذاكرة، وهذه كلها عنده من أصل حسيّ. - المعقولات الهيولانية، وهي المعاني المجردة والمفاهيم الكُّيّة المستخلصة بالتجريد من

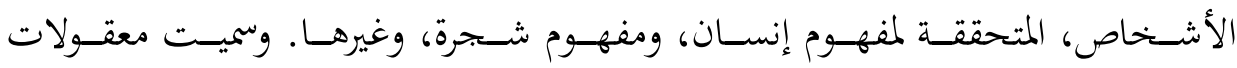
هيولانية؛ ؛ُ لأها منتزعة من الهيولى أو المادة.

- العقل الفعّال والعقل المستفاد: وهما صورتان لا تحتاجـان في وجودهما إلى هيولى،

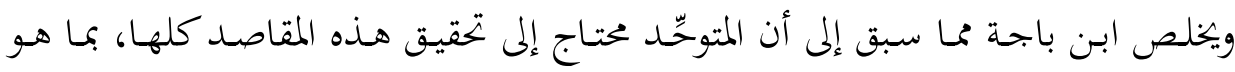

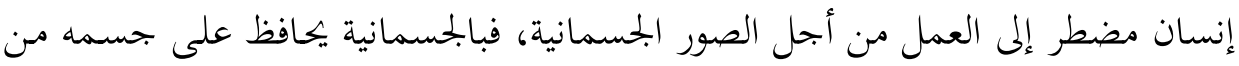

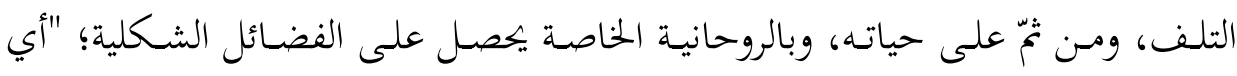

ro والصور الروحانية عند ابن باجة فيها معادلة من الجسد والنفس بوصفها جواهر ساكنة محركة لما سواها، فتكون بهذا

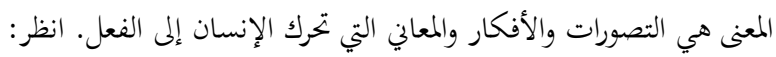

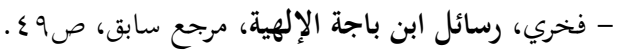

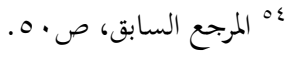




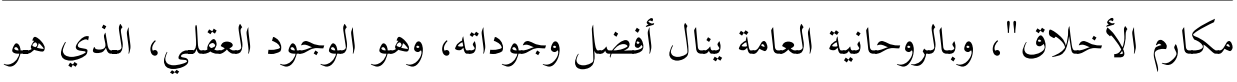

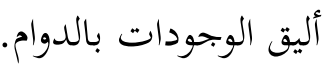

\section{الأفعال الإنسانية والسِّن:}

يربط ابن باجة بين أفعال الإنسان ومراحل عمره المختلفة، فيرى أن لكل سِنّ يمر بها

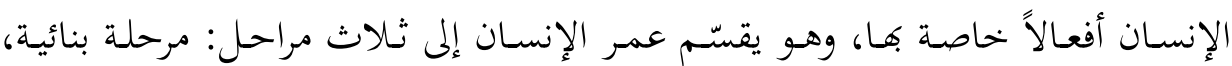
ومرحلة حيوانية، ومرحلة إنسانية.

أ. أما المرحلة البنائية، فهي بسنّ الطفولة، وفي هذه المرحلة تكون كلُ أفعاله بدافع من النفس الغاذية (من التغذّي).

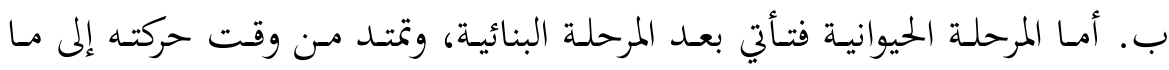

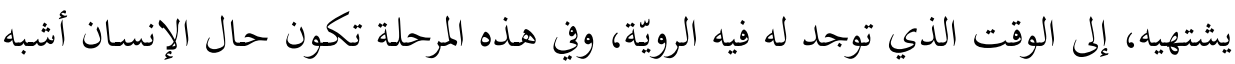
بحال الحيوان غير الناطق، وتكون السيطرة للنفس البهيمية التي تفعل الأفعال بطابعها.

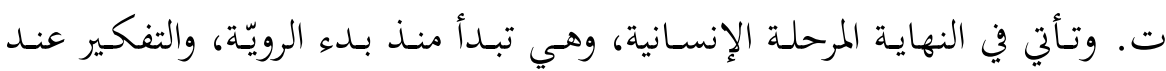

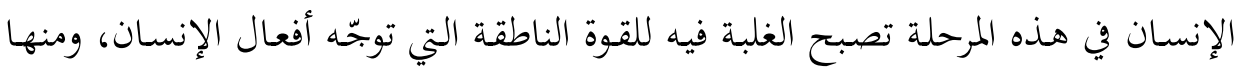

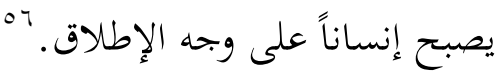

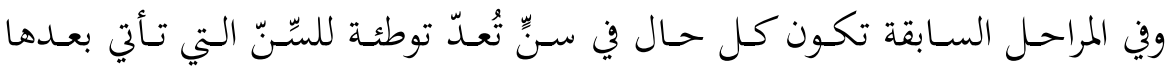

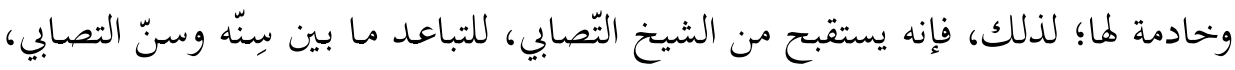

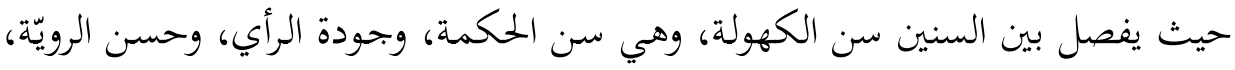

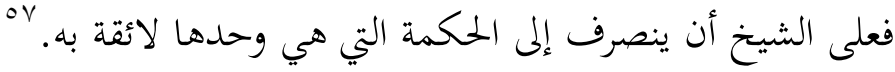

وعلى الجملة فإن ابن باجة يذهب إلى أن الإنسان الفاضل حقاً والعاقل حقاً، إنما

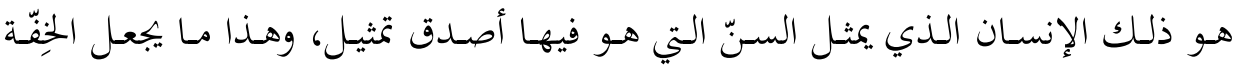

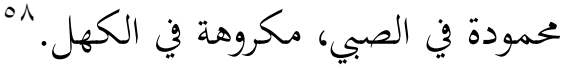

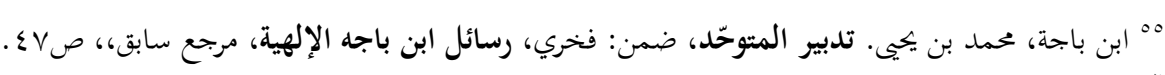

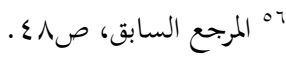

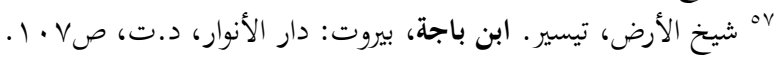

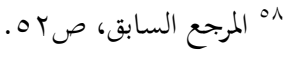




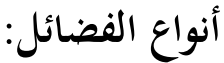

أ. الفضـائل الفكريـة: وهـي العلـوم، ومـا جــانس هـذه كصـواب المشـورة، وجـودة الاستنباط، وبعض الصنائع داخلة في هذه.

ب. الفضائل الشكلية: كالسخاء، والنجدة، والألفة، وهذه الأفعال على الإجمال قد

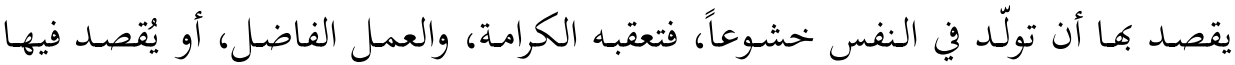
شيء، فيحصل عنها كمال صورته الروحانية.

\section{مراتب الناس في تحصيل الفضائل والكمالات:}

يرى ابن باجة أن الاختلاف في الأفعال، هو الذي يجعل الناس يتفاوتون في المراتب،

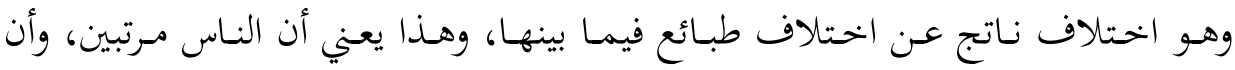
مراتبهم مرتبطة بمراتب أفعالهم. ويكصر ابن ماجة المراتب فيما يأتي: 9ه أ. المرتبة الجسمانية الخالصة، وتعني أن الأشخاص الذين يدخلون في هذه المرتبة هـم أحسن الجسمانيين. وهم لا يحفلون بالصورة الروحانية، ولا يلتفتون إليها. ب. المرتبة الجمسمانية الروحانية: وهذه المرتبة أعلى من السابقة، وهي بدورها تتضمن مرتبتين مختلفتين بحسب تغليب الصورة الروحانية على الصورة الجسمانية أو عدم تغليبها. ت. المرتبة الروحانية العقلية: وتتضمن هذه المرتبة في الحقيقة مرتبتين بحسب تغليب الصورة العقلية على الصورة الروحانية، أو عدم هذا التغليب. وهي من هذه الناحية شبيهة بالمرتبة الجحمانية الروحانية، غير أن المرئية التي تكون الغلبة فيها للصورة العقلية هي أعلى المرتبتين دون شك.

وبذلك يتضح أن مراتب الأفعال ترتبط بمراتب الناس، سواء من حيث المراكز التي

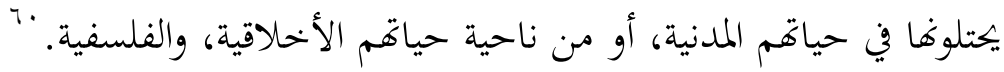

$$
\begin{aligned}
& \text { •• المرجع السابق، ص9 v. } \\
& \text { “" راجع في ذلك: لمرجع. }
\end{aligned}
$$




\section{تحصيل السعادة هو الغاية القصوى للسلوك الأخلاقي:}

\section{أ. طريقة تحصيل السعادة:}

يكصر ابـن باجـة طريقـة تحصيل السعادة للمتوحِّدـ في طريق علم الصـور الروحانيـة، وعلى المتوحّد في هذه الحالة أن "يعتزل الناس جملة، فلا يلابسهم إلا في الأمور الضرورية. وهذه العزلة أو الهجرة ليست غاية في ذاقها، ولا هي من الأمور الطبيعية، وإنما هي مـن أجل طلب صحة النفس."Ir" ب. ب. المتوحّد وتحصيل السعادة:

الغاية القصوى التي يصبو إليها "المتوحِّد" في المدينة الفاضلة هي الاتصـال بالعقل الفعال، ومن وراء ذلك اللحاق بعالم المفارِقات، الذي ذهب كلهّ من الفارابي، وابن باجة

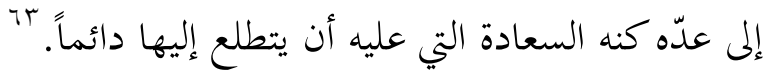

والكمـال الذي يوصل إلى هذه السعادة يكمـن في أن سعادة المتوحِّد لا تكمـن في

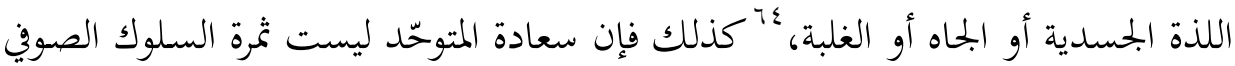
الذي يهمل العلم، ويكتفي بـالخلوة. قـال ابـن باجـة: "زعم الصـوفية أن إدراك السعادة

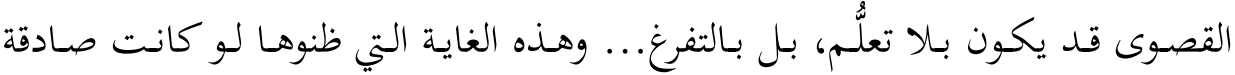
وغايةً المتوحد، لبقي أشرف أجزاء الإنسان لا عمل له، وكان وجوده باطلاً، وكان يبطل

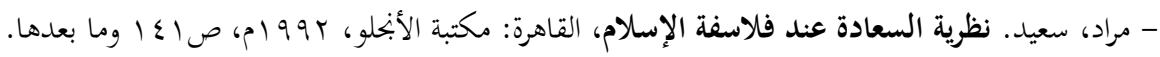

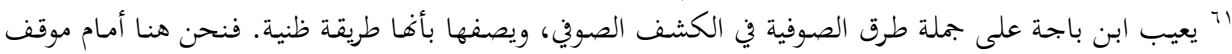

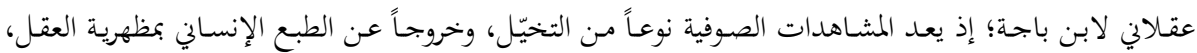

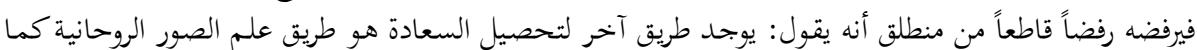

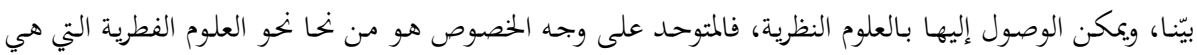

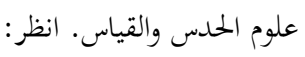

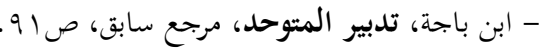

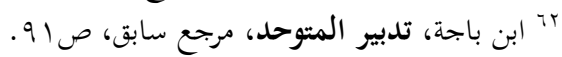

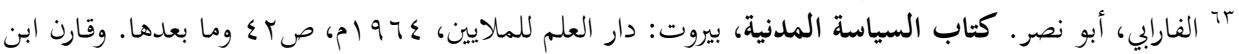

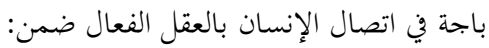

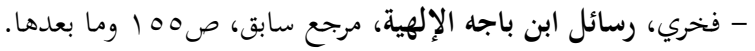

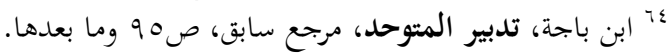


جميع التعاليم، والعلوم الثلاثة التي هي الحكمة النظرية." "جومن ذلك يرى ابن باجـة أن

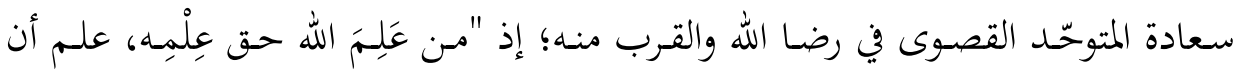

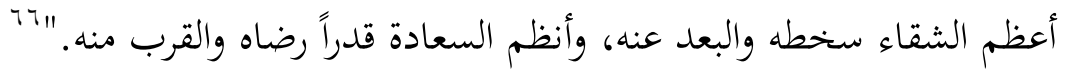

وابن باجـة لا ينسى أنه فيلسوف مسلم، يـعو الإنسـان إلى طاعة الله، والعمل بمـا يرضيه حتى يثيبه الله العقل الذي يهتدي به في تحصيل السعادة، على أن الإنسان لا يعلم

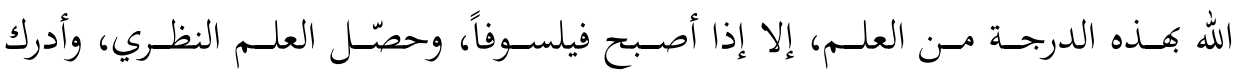
المعقولات والعقول البسيطة، وأصبح كاملاً بالكمال الخاص به، وكاملاً كإنسان عاقل. فالعقـل سبيلنا إلى العلـم النظري، وهـذا العلـم هـو سـبيلنا إلى الله وإلى السـعادة؛ أو

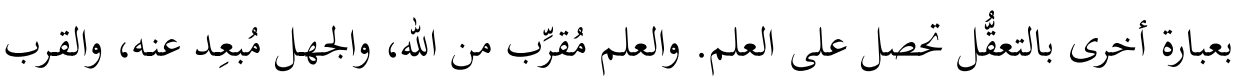

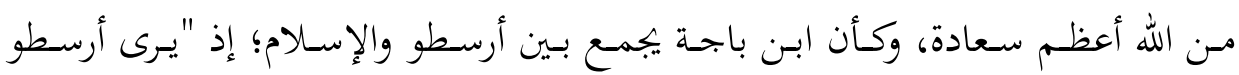

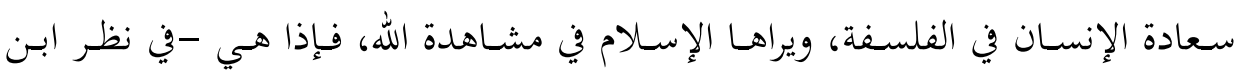

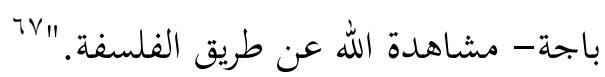

والسعادة عند ابن باجة بهذا المعنى لا تتوقف عند الفرد، وإنما ينبغي أن تتخطاه إلى

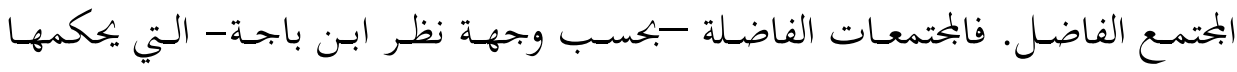
المتوحِّد، بحتمعات سعيدة في الوقت نفسه.

\section{رابعاً: أبو بكر بن طفيل وأخلاق "حيّ"}

يعدّ أبو بكر بن طفيل ^^ المعلم الثاني في تاريخ الفلسفة الأندلسية، ويعود الفضل في شهرة ابن طفيل إلى قصته الرمزيـة (حي بن يقظان)، 79 فهي المصدر الوحيد للاطلاع

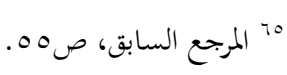

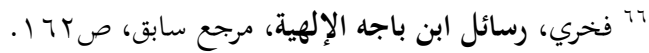

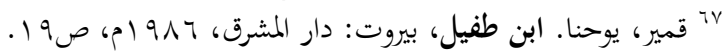

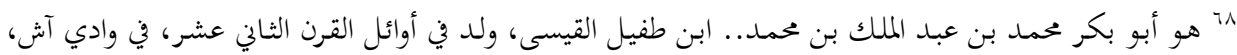

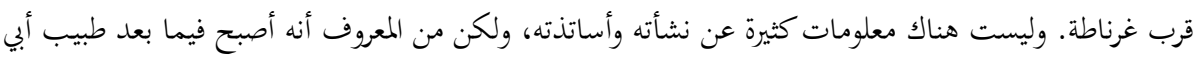

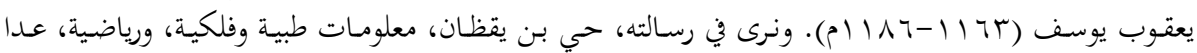


على آراء هـذا الفيلسـوف، سـواء المتعلق منهـا بفلسفتهه الإلهيـة الطبيعيـة بوجـه عـام، أو المتعلق منها بفلسفته الأخلاقية بوجه خاص.

\section{الآراء الأخلاقية لابن طفيل:}

سار ابن طفيل في سرد آرائه الأخحلاقية على هـج ابن باجـة. ‘ط وعلى منواله كان مفهومـهـ عـن السـعادة الـتي أودعهـا في قصسته الفلسـفية المشـهورة (حسي بـن يقظـان). وسنعرض للجوانب المختلفة لمذه الآراء بشيء من التفصيل:

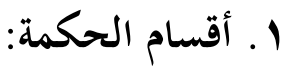

ينحو ابن طفيل نحو أرسطو في اعتبار أن احتياجات الإنسان، وتدبير أعماله هي السبب في نشأة الحكمـة العلميـة مـن أخهاق، وسياسـة، وتـدبير لشؤون المنـزل. ومسن ثم انقسمت هذه الحكمة العملية إلى ثلاثة أقسام، وفقاً لقوى الإنسان الثلاث:

مذهبه الفلسفي، فقد كان شديد الولع بالعلوم والفلسفة، مما يدل على ثقافة عميقه وشاملة. وقد خحدم ابن طفيل

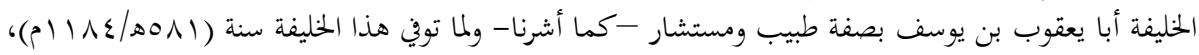

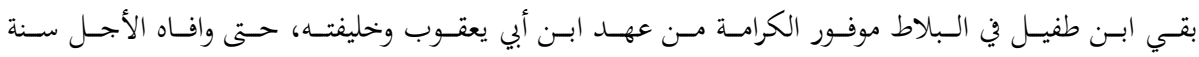

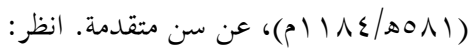

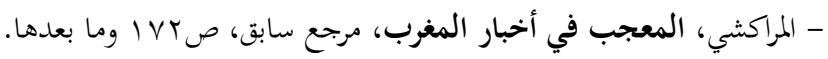

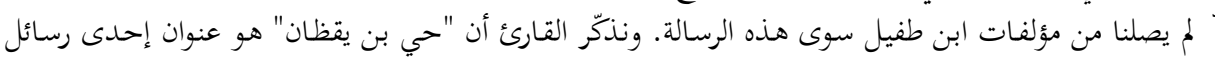

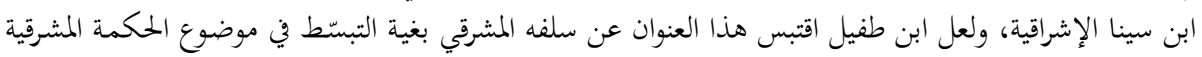

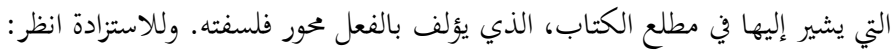

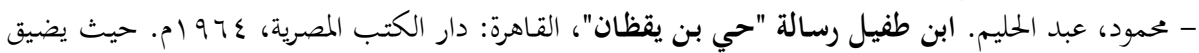
بكثنا هذا عن سرد تفاصيلها.

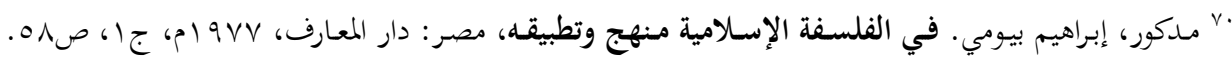

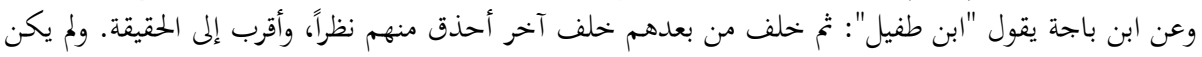

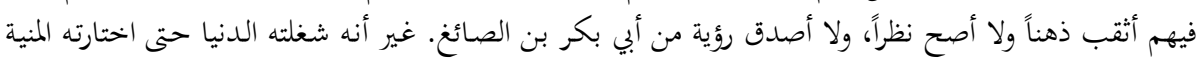

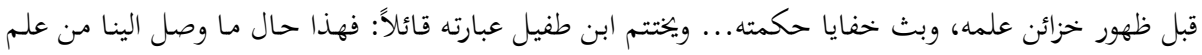

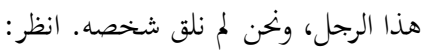

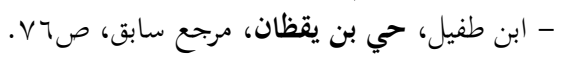
- Munk, Salomon. Mélanges de philosophie juive et arabe, Paris: Lib. Philosophique J. Vrin 1955, pp. 414-415. 
أ. القسـم الأول: وفيـه الأعمـال الخاصـة بالبـدن، ومـا فيهـا مـن تنظيم لعمليـات

الاغتذاء من مأكل، ومشرب، وملبس وغير ذلك.

ب. القسم الثاني: وفيه الأعمال الخاصة بالروح الحيواني المدبّر لقوى البدن، وتشتمل على أعمال التطهير والاغتسال والنظافة.... ثم إن هناك أفعال الحركة المختلفة. ت. القسم الثالث: وفيه يحاول التشبُّه بالصانع، لأجل الاستغراق، والمشاهدة، ومن

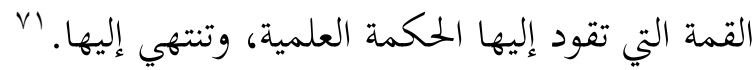

وهذه المراحل في جملتها يمر بها (حيّ) في مراحل حياته من أعمال البدن، وحِفْظ الحيـاة، وسياسـة القـوت والغـذاء، وأصــاف الغـذاء الـتي تلائمسه، ثم ينتقـل إلى أعمـال الطهارة، والاغتسال حتى يتشبه (حيّ) بالأجرام السماوية. تم تجيء المرحلة الأخيرة وهي التي يختص (حيّ) فيها بتأمل الموجود الأول أو الخالق (تأمل عالم ما بعد الطبيعة).

\section{Y ب اية الحكمة العملية:}

وغاية الحكمة العملية عند (حيّ) هي الكشف، والمشاهدة، والإشراق. فالعبادات مع ابن يقظان تنحو منحى صوفياً، وهو تصوّف ليس كالتصوف المعروف لدينا؛ لأنه عقلي مضض.... وماهية الكشف والمشاهدة - كما يرى حيّ- لا يمكن الكلام عنها إلا رمزاً. والعبارات في جملتها هي طريق يرقى من البدن إلى الروح السماوي، َ وذلك مـن خهالال تطهير النفس، وتنزيهـا على أساس من الفعل العقلي، والفهم الكامل للوجود.

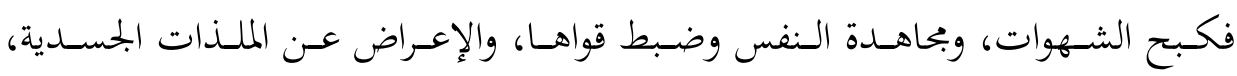
والاكتفاء بالقليل من الاغتذاء، والمسكن، والملبس لحاجة البدن الضرورية، إنما هو سبيل (حسيّ) في تحقيـق غايتـه في الوصـول إلى الحلكمـة العمليـة، التي غايتهـا الحـق عـن طريـق

$$
\text { المشاهدة والاستغراق. }
$$

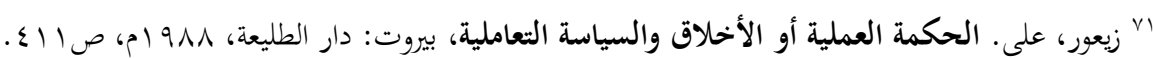

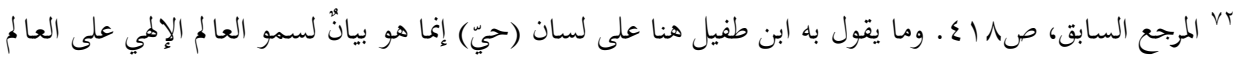

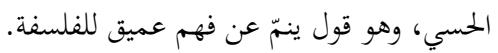

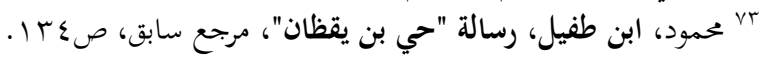




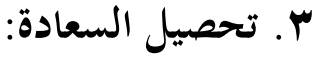

يتعرض ابن طفيل لأصـاف البشـر وحظهم مـن السعادة، فيتحـدث عن الذين لم

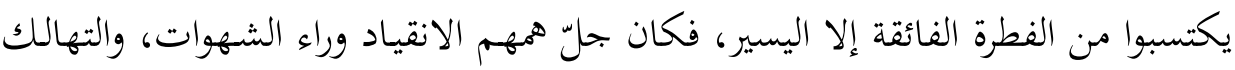

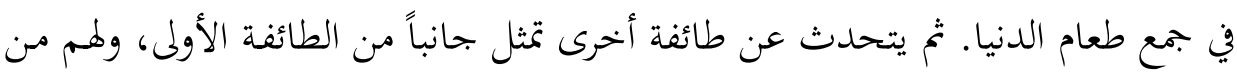
الفطرة السـليمة نصسيب أوفى، هـؤلاء هـم المتّبعـون لما جـاء في الشـريعة الإلهيـة، المـؤثرون للحياة مع جمهور النـاس في المدينة. أما الطائفة الثالثة فهم أصحاب الفطرة الفائقة، أو

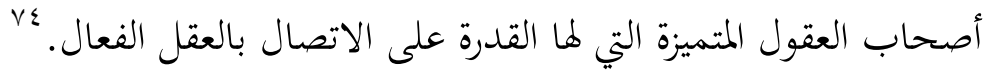

أمـا أصحاب السعادة القصوى، فتتحقق لهم السعادة القصوى في طريقة "الاتصال الحق" عنده، وهو طريق عقلاني يكون التفكير فيه ملازماً لواجب الوجود، وقطع العلائق

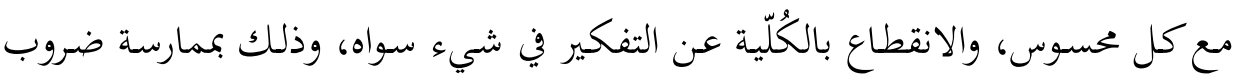
البحاهدة، والتحرر من ربقة الجسد.

\section{ع. الفضائل الأخحلاقية، وتقسم إلى:}

$$
\text { - فضيلة الانسجام مع الطبيعة: }
$$

وفيها يجـب ألا يتعـارض الإنسـان مـع الطبيعـة بـأي حـال مـن الأحسوال، فبإن لكل موجود في هذا العالم سواء أكان نباتاً أم حيواناً، غايةً خاصة به. فمن طبيعة الفاكهة مثلاًَ- أن تنضـج، ويسقط نواهـا على الأرض، ليخرج مـن كل نواة شجرة جديدة، فياذا لها قطف الإنسان هذه الثمرة قبل نضجها فإن عمله هذا يُعدّ بعيداً عن الأخلاق؛ لأنه يمنع النبـت مـن أن يحقـق غايتهـ في هـذا الوجـود... وكـذلك بالنسـبة للحيـوان ومســاعدته إذا احتاج إلى العون... وإزالة عوائق جريـان الماء، وإزالة النباتات المعيقـة لنباتات أخرى... وكلها أعمال من شأها تحقيق الانسجام مع الطبيعة والرأفة بها، وقد برزت هذه الجوانب

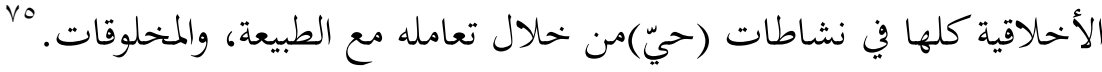

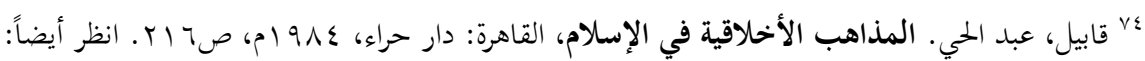

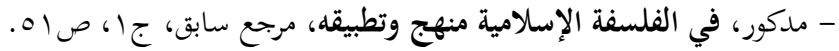

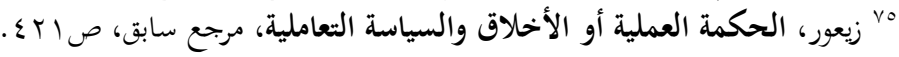


وهي عند ابن طفيل المحرك لكل سلوك، فهو يوحّد بين الطبيعة والإنسـان داخل شبكة من التعاون لا الصراع، ب والدليل على ذلك من قصة (حيّ) ما ظهر من رعاية (حيّ) للطبيعة التي تعهدته بالرعاية حين هرمت، فقد اتسمت علاقته بها بالوقار، والمحبة. وكان يرتاد بها المراعي الخصبة، ويجتني لما الثمار الحلوة، ويطعمها، ولما ماتت حزن عليها حزناً شـيداً. وابن طفيل هنـا لا يخرج عمّا قال بـه الفقهاء، والوعـاظ، والفلاسفة فيمـا يتعلق بالحِكمـة العمليـة التي تنظم العلاقـات الاجتماعيـة، والعائليـة وفقق مبـادئ مثاليـة، ومنها: احترام الكبير، وتقدير الوالدين، والرأفة بهما في الكبر.

\section{هـ مكانة الأخلاق الوضعية عند "حيّ":}

لم يتعرض ابن طفيل للأخهاق الوضعية مـن دينية أو اجتماعية، فقد اهتمّ بإنسان يعيش في بيئة طبيعية لا يعرف بيئته الاجتماعية، ثم إن الأخلاق الوضعية ليست غايات في ذاتا، بل هي طريق إلى غايات أخرى. وبيان ذلك أن بحارب (حيّ) أثبتت أن العقل البشري قادر على الوصول إلى الحقيقة بمفرده، وأنه قادر على تنظيم شؤون الفرد، وضبط أحوال المحتمع على وجهه أفضل، وفي ذلك لا حاجة لعون خارجي ينظم للإنسان أموره أو يساعده على تحسين شروط إقامته على الوجه الأكمل. وينتهي ابن طفيل إلى التأكيد على أن الحكمة العملية المستمدة من الشرع في النهاية مع حكمة العقل؛ فالحكمتان: العملية والنظرية يلتقيـان معاً، وإذاكـان هنـاك فـارق بـين الحكمتــن، فهو في الطريق، وهـو فـارق يتمثل في أنّ ثمـة واحـدة منـزَّلة، وهـي

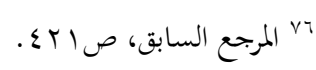

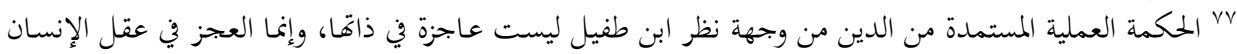

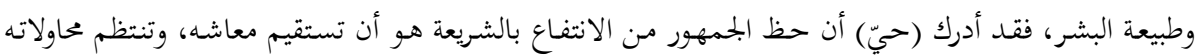

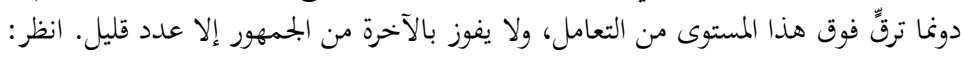

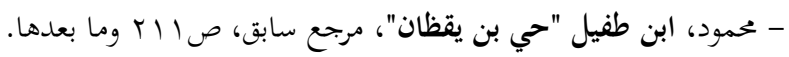


للعامة مـن الناس، وأخرى بشرية للخاصة. وهو مـا سيقول بـه ابن رشد بعد ذلك في معالجته لأخلاق الخواص والعوام.

\section{خامساً: ابن رشد "وأخلاق الخواص والعوام"}

لم يفرد ابن رشد ^`بحالاً مستقلاً لدراسة الأخلاق على نحو تفصيلي، لكنّا سنحاول

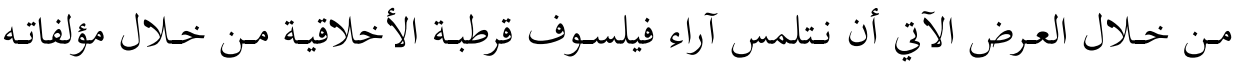

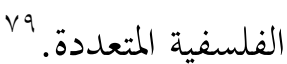

\section{1 ـ مكانة علم الأخلاق في مؤلفات ابن رشد الفلسفية:}

علم الأخـالاق عندـ ابن رشـد مستقل عن سياسـة النفس، ومـتبط بعلم السياسـة

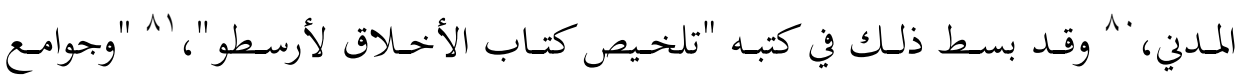

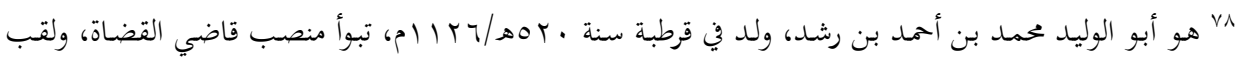

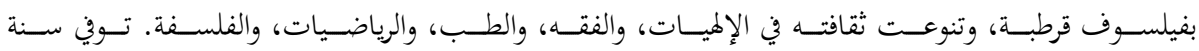

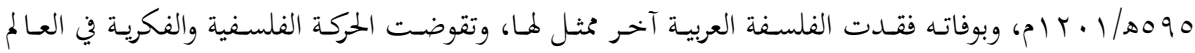

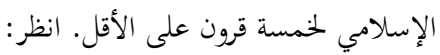

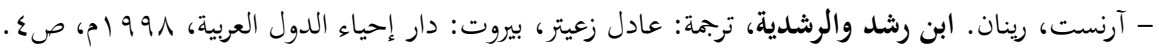

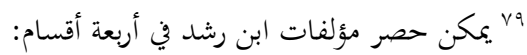

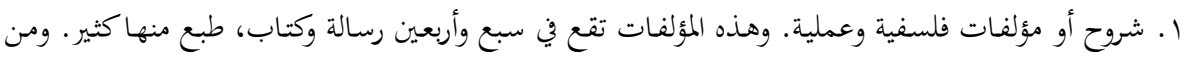

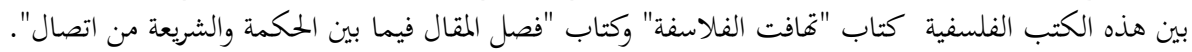

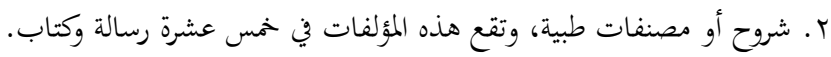
r. مؤلفات فقهية وكلامية وتقع في سبع رسائل وكتاب.

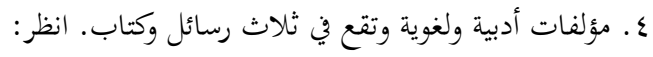

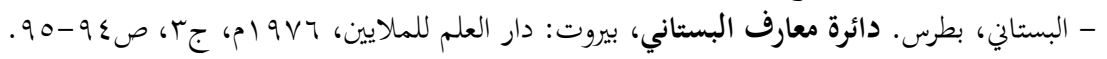

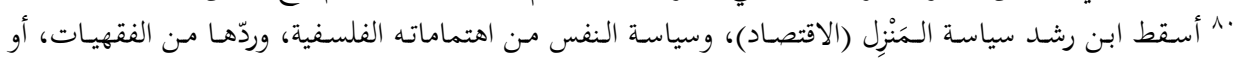

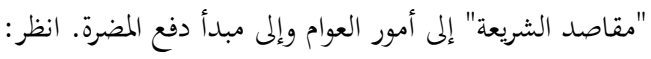

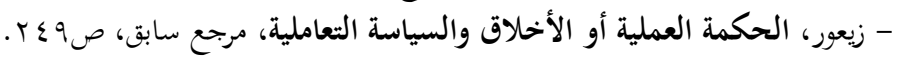

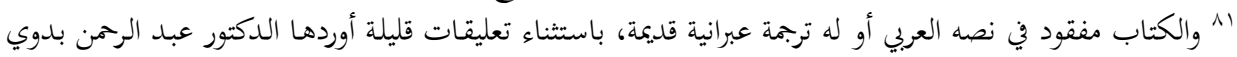

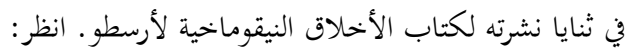

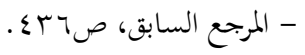




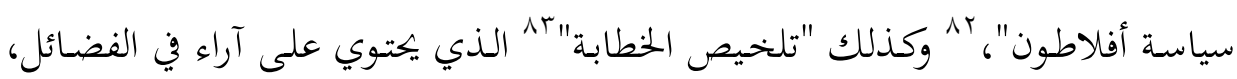
وكتـاب "تلخـيص الـنفس لأرسطو" ضـمن جوامـع كتـب أرسطو طـاليس في الطبيعيـات والإلهيـات. هــا بالإضـافة إلى إشـارات مقتضـبة إلى قضـايا أخلاقيـة في بعض مؤلفاتـه

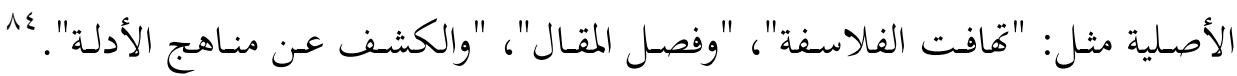

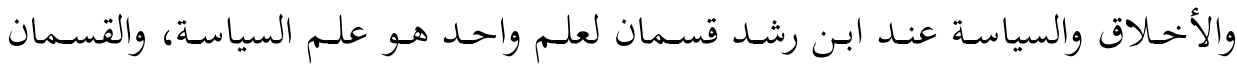
مرتبطان ببعضهما؛ ارتبـاط المبدأ أو النظري بالممكن أو العملي، على غرار ارتباط علم

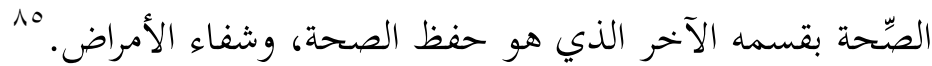

\section{r. آراء ابن رشد في الأخلاق:}

يعتمد ابن رشد مذهب أرسطو في الأخلاق، فالأخلاقيات في الصياغة الأرسطية في (النيقوماخيـا: وهـو كتابـه في الأخهلاق) هـي أقـرب إلى الواقعيـة العقلانيـة مـن الصـياغة الأفلاطونية، ويذهب بعضهم ب^ إلى أن الفلسفة العربية قد رأت نفسها متمثلة، أو معبراً عنها في التقسيم الأرسطي للفضـائل. ونحن نوافق هـا الرأي، فقـد كان أرسطو بالفعل سباقاً في صياغته قواعد علم الأخلاق التي أثّرت تأثيراً كبيراً في الفلاسفة المسلمين، ومنهم

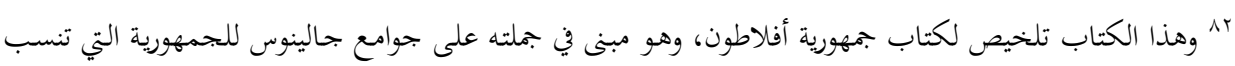

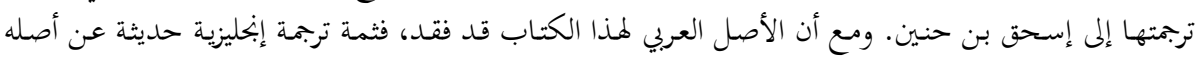

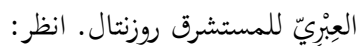

- Averroes. Averroes' Commentary on Plato's "Republic", edited with an introduction, translation and notes by E. I. J. Rosenthal, Cambridge, UK.: Cambridge University Press, 1966.

- ابن رشـد، أبو الوليـد. تلخسيص الخطابـة لأرسطو، تحقيق: عبد الرحمن بـدوي، بيروت: دار القلم، طا، .1909 §^^ نشرة كلية الآداب والعلوم الإنسانية جامعة محمد الخامس/ المغرب، ضمن: أعمال ندوة ابن رشد، ومدرسته في

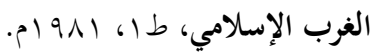

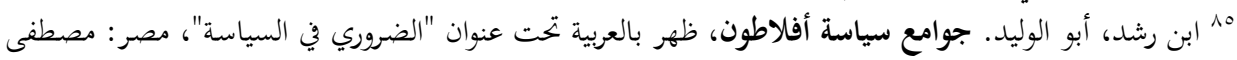

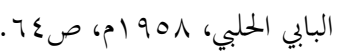

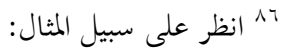
- زيعور، الحكمة العملية أولاً الأخلاق والسياسة التعاملية، مرجع سابق، صبr؟ـ 
ابن رشد الذي أكثر من الالتجاء إلى (النيقوماخيا) في عرضه لمذهبه في الأخلاق داخل

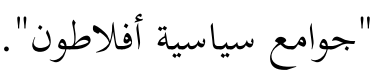

\section{أ. طرق غرس الفضائل في النفوس:}

يرى ابن رشد أن لغرس الفضائل في نفوس سكان الدولة سبيلين رئيسين: الإقناع

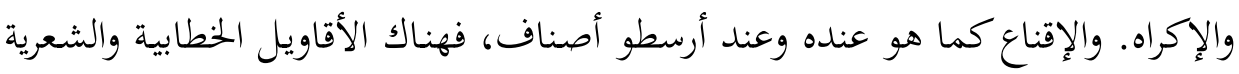

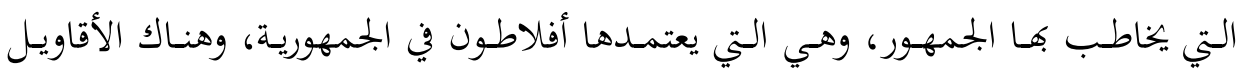

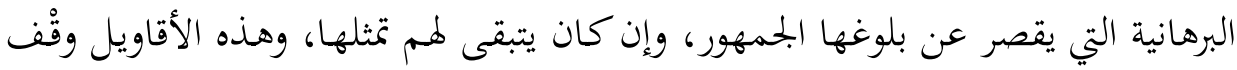

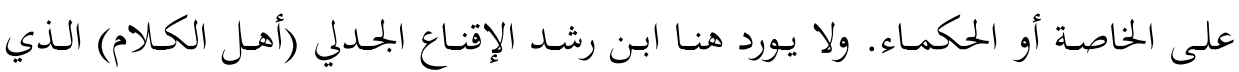

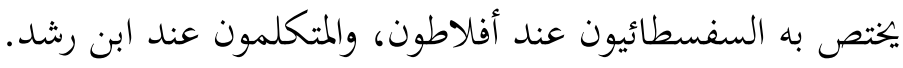

أمـا الإكراه، ويلتجـأ إليسه في حـال تعــر الإقنـاع، فـلا يكـون إلا للأعـداء، وغـير

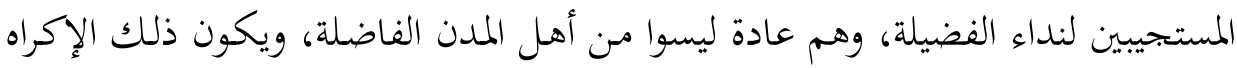

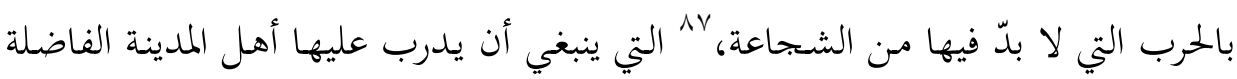

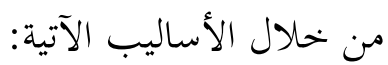

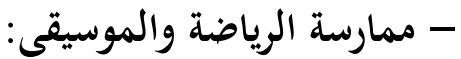

ولكي يتم غرس خصال الشجاعة من قوة جدية، وسرعة، وحركة، ووحدة (إدراك)

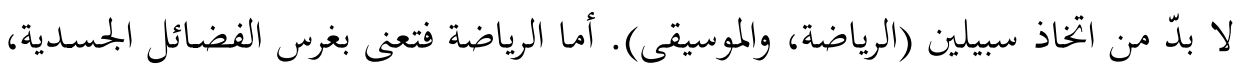

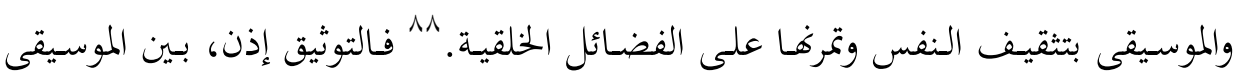

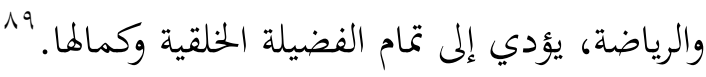

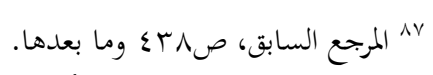

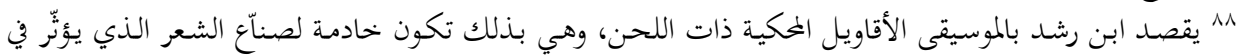

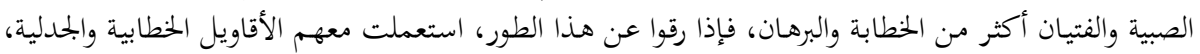

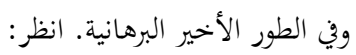

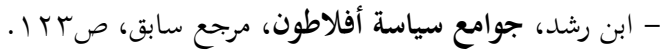

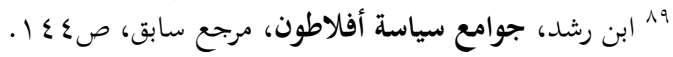




\section{- التدرُّج في طلب العلم والحكمة:}

وفيها ينبغي على المتربِّين في المدينة الفاضـلة أن ينصرفوا عـن طلب الثروة، وعن

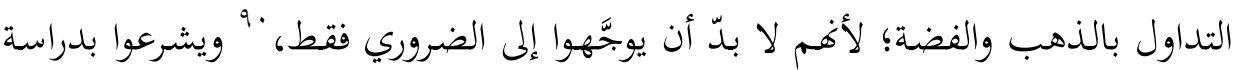

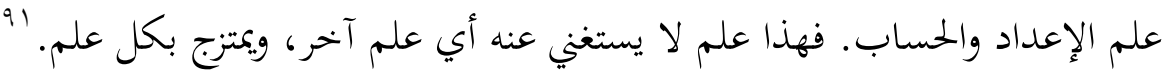
وبعد هذه يتعلمون الهندسة، فعلم الموسيقى والفلك. ثم يقبلون عند بلوغ السادسة

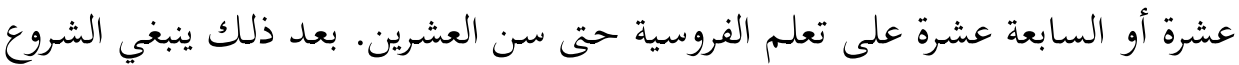

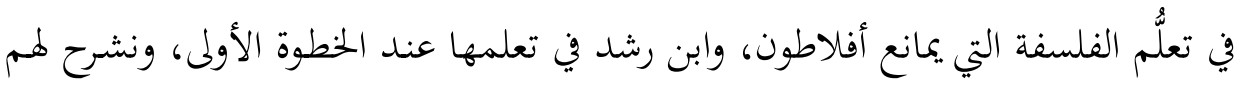

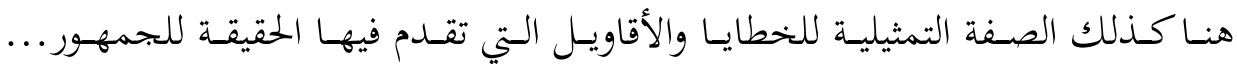

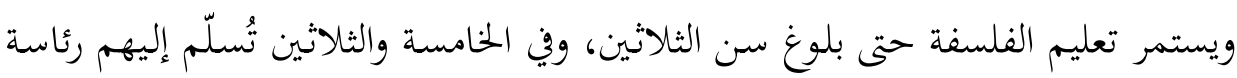

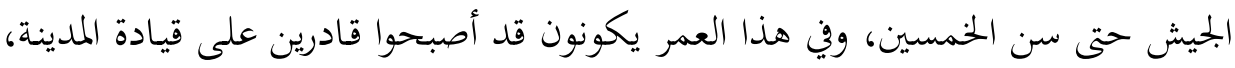
وإدارة الأمور العامة.

ب. الفضائل أو الخصال التي ينبغي أن يتحلى بها الحاكم:

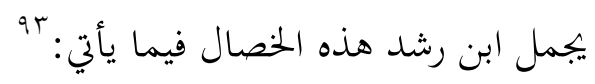

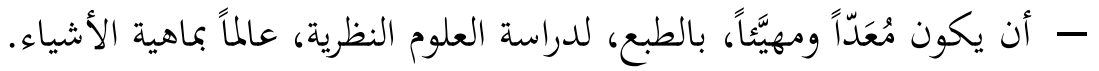

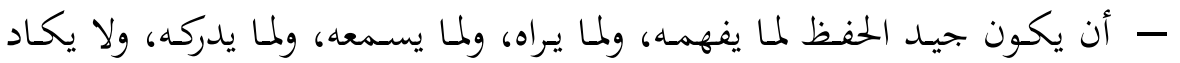
ينساه.

- أن يكون محباً للعلم، وبتحصيل العلوم بشتى فروعها، ويكون راغباً بمعرفة كل أنواع المعارف. - أن يكون محباً للصدق وأهله، ومبغضاً للكذب وأهله.

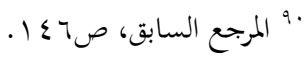

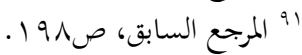

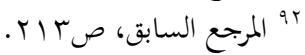

$$
\begin{aligned}
& \text { ro المرجع السابق، صr r r وما بعدها. }
\end{aligned}
$$


- أن يكون غير شَرٍِ على المأكول، والمشروب، والمنكوح، وغيرَ محب للمال. - أن يكون جيد الفطنة، جيد الاستنباط، وشجاعاً قوي العزيمة. - أن يكون بليغاً حَسنَ العبارة.

\section{ت. الشريعة قوام الحكمة للجمهور:}

يخصص ابن رشد للجمهور حكمة قوامها الشريعة، والمعروف أن لتلك الحكمة أو الشـرع ظـاهراً وباطنـاً، ومـن هنـا يجــب التأويـل والاقتصـار على تعلـيم الظـاهر للنـاس...

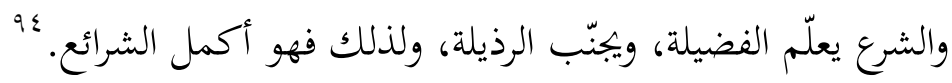
وفي المقابل يضع ابن رشد لأهل البرهان منهجاً آخر، يعلمهم فيه عدم جواز الخوض والجـدال في مبـادئ الشـرائع؛ لأن "الصـناعة العمليـة الشـرعية أحــى بــلك، ولأن المشـي على الفضائل الشـرعية هو ضـروري عندهم.... ولذلك يجـب على كل إنسـان أن يسلّم بمبادئ الشريعة، وأن يقلد فيها." ه9 والشرائع تقصد إلى تعليم الجمهور عامة، والوحي هو رحمة للجمهور؛ الأمر الذي يوجب عليهم التقليد، وكل ما ينبغي على أهل البرهان عدم كشف تأويل ذلك للجمهور. والأمـر الواضـح هنـا أن ابـن رشــ وضـع الجمهـور، وأهـل الجـدل والكـلام في منـزلة واحسدة، على الرغم من تخصيصه منهجاً مستقلاً لكل منهما، وكذلك تخصصيه موقفاً اجتماعياً، ومرتبة للتصديق لكل منهما.

\section{ث. تحصيل السعادة: - ت}

ينهج ابن رشد منهج أرسطو في تحديد وسائل تحقيق السعادة، ويكصرها في الاعتماد على العقل، والدرس، وتنمية القوى الإنسانية، حتى يصل العقل في مراحل متقدمة إلى §ج" ابن رشد، أبو الوليد. فصل المقال فيما بين الحكمة والثريعة بين اتصال، مصر: المطبعة الجمهورية التجارية،

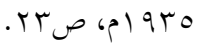

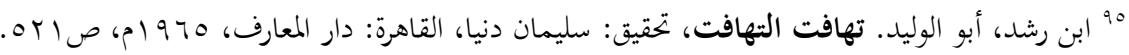

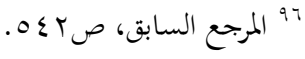


الاتصـال بعـالم العقـول المفارقـة والأرواح، لو الـتي بمقتضــاهـا تتحقـق للإنسـان السـعادة القصوى. والسعادة لما مرتبتان هما:

- السعادة المشتركة (السعادة العامة): وهي تلك الدرجة من السعادة الممكنة للناس

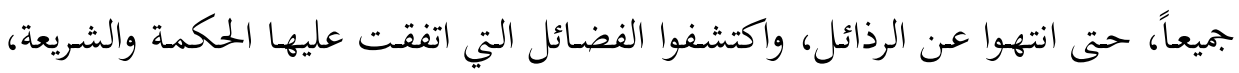

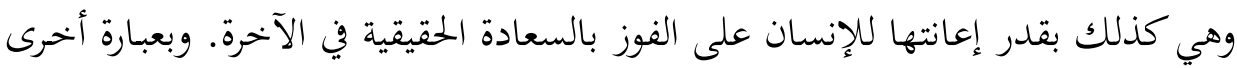
فإن ابن رشـد يرى أن السعادة المشتركة بين النـاس تحصل باتباع كل فضيلة يدعو إليها

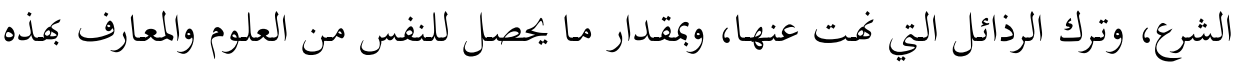
الفضائل تكون السعادة، مج وهذا ما ورد في كل الشرائع محا يجب ولت ولا يمكن إنكاره. - السـعادة الحقيقيـة (السـعادة الخاصـة): وهـي السـعادة الـتي تُعـرف عنــ جمهـور

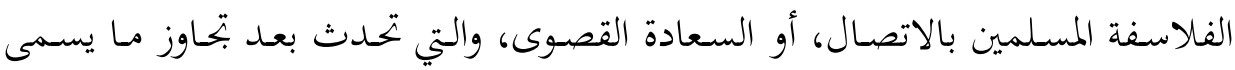

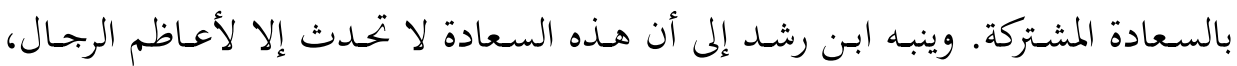
وهم يدركوها في الشيخوخة أو على فراث الموت. 99

وقول ابـن رشـد بضرورة تحصيل السعادة الحقيقيـة في الحيـاة الـدنيا يجيء فيه متـأثراً

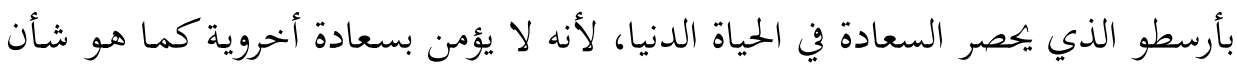
العقيدة الإسلامية، ولكن على الرغم من وجود الأثر الأرسطي في فلسفة ابن رشد، بجد الأثر الإسلامي فيها أوضح ما يكون منذ إقراره بسعادة دنيوية وأخروية.

وابن رشد على الجملة يرى أن السعادة تتحقق بالكمال، والكمال يعني الحصول

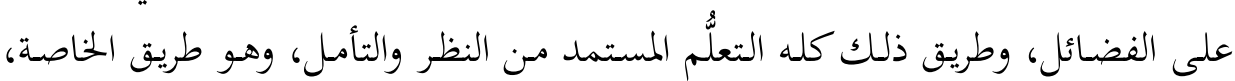
الـذي يغلب عليـه النهج الفلسـفي الخـالص على الكشـف الصـوفي الوجــاني، هـذا مـن ناحية، ومن ناحية أخرى تحقيق الكمال كذلك في التمسك بالشرع، وهو طريق العوام. Vو ابن رشد، أبو الوليد. تلخيص كتاب النفس، تحقيق وتقديم: أحمد فؤاد الأهواني، القاهرة: مكتبة النهضة المصرية، المائ.

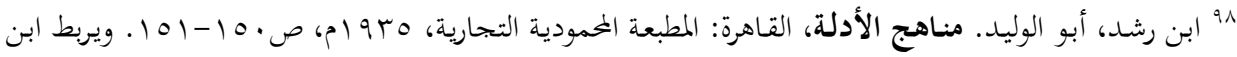

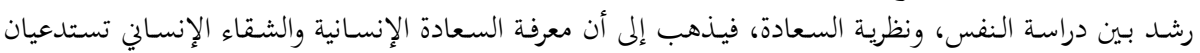

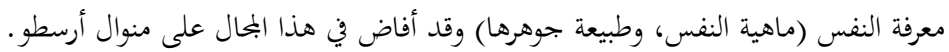

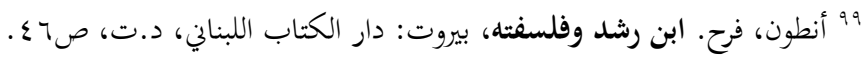




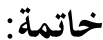

تناولت هذه الدراسة جانباً مهماً من جوانب الفكر الفلسفي، وهو المتعلق (بالجانب

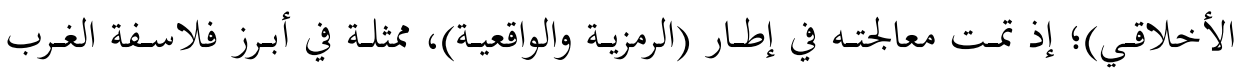
الإسلامي على وجهه التحديد، وذلك لتوفر هذين النوعين مـن المعالجـة في إطار تناولهم الفلسـفي للقضـايا الأخلاقيـة. وقـد جـاءت دراسـات مفكـري الغـرب الإسـلامي -محل المعالجة- في إطار وثيق الصلة بالأوضاع السياسية والاجتماعية السائدة في عصرهم. فقد نحا ابن حزم الأندلسي منهجاً واقعياً في معالجة الجحانب الأخلاقي في فلسفته؛ إذ إذ

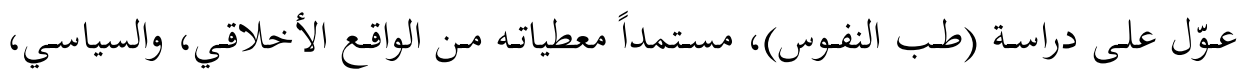

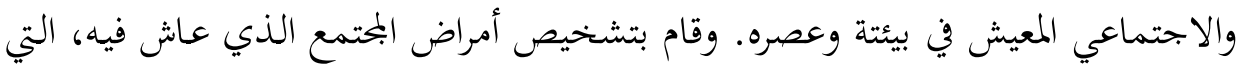

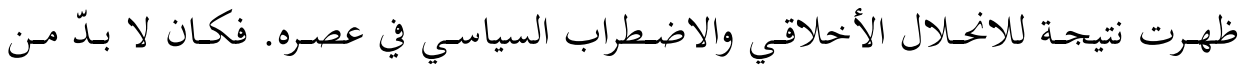

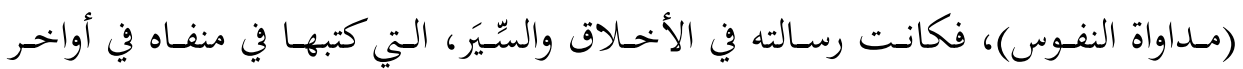
حياته، وكذلك رسالته الموسومة (طوق الحمامة).

وكان ابن حزم يداوي النفوس بإصلاح السير والأخلاق، وقام بحصر آفات النفوس،

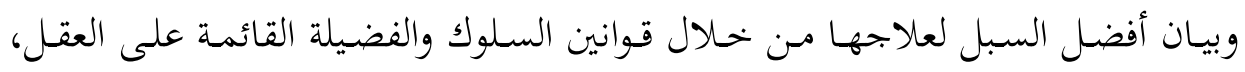
والمؤيدة بأحكام الشرع، لذلك تنوعت مصادر ابن حزم في دراسة الأخلاق، ما بين آراء فلسفية يونانية وأخرى دينية مستمدة مـ معطيات الشرع (الكتاب والسنة)، لتحقيق هدف أسمى، هو دفع الهمّ عن طريق طلب ما عند الله.

أما الرمزية في المعالجة الأخلاقية فظهرت عند ابن باجة؛ إذ عرض بحمل القضايا من

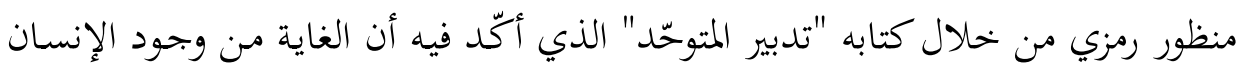
هي القرب من الله تعالى عن طريق العلم، وحُبِّ الحكمة، والاتصال بالعقل الفعّال، متأثراً في ذلك بفلسفة الفارابي الأخلاقية. 
وتستمر المعالجحة "الرمزية" للمسائل الأخلاقية عند ابن طفيل، الذي أكّد كثيراً من

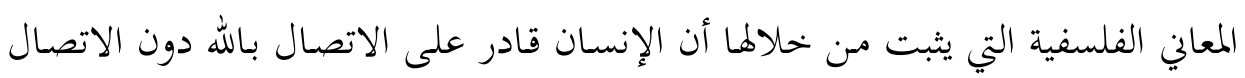

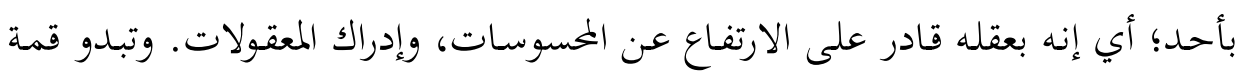

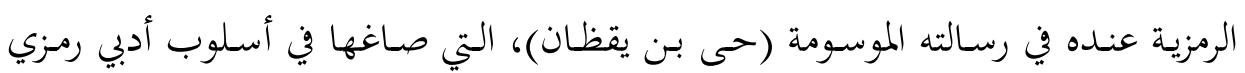

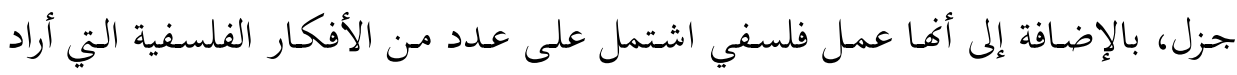

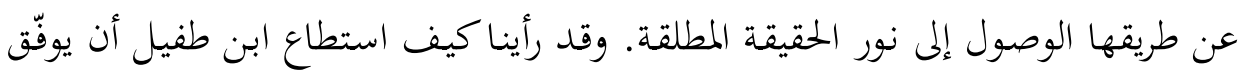

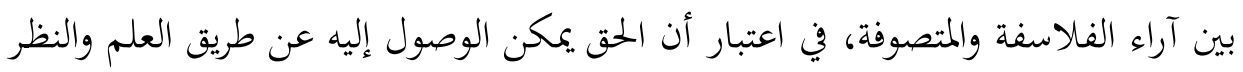
أولاً، ثم عن طريق الذوق والتأمل ثانياً.

وإذا كان ابن باجة وابن طفيل قد استخدما الأسلوب الرمزي والخيالي في معالجتهما

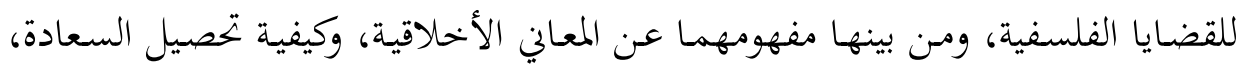

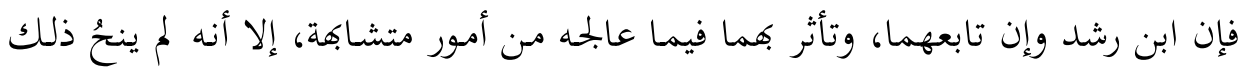

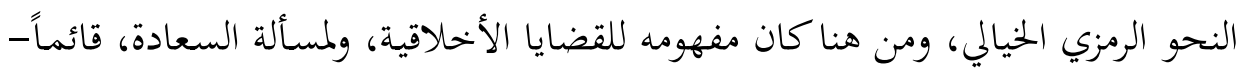

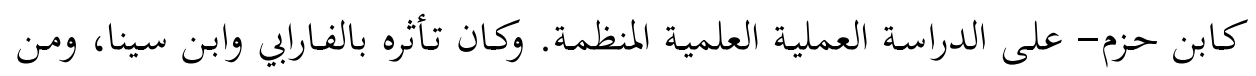

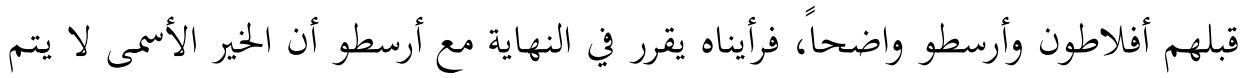

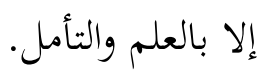

